\title{
An Assessment of Environmental Health and Safety Issues \\ Associated with the \\ Commercialization of \\ Unconventional Gas Recovery: \\ Devonian Shale
}

Project Manager

E. F. Riedel

September 1981

Prepared for the U.S. Department of Energy under Contract DE-AC06-76RLO 1830

Pacific Northwest Laboratory

Operated for the U.S. Department of Energy

by Battelle Memorial Institute 
NOTICE

This report was prepared as an account of work sponsored by the United States Government. Neither the United States nor the Department of Energy, nor any of their employees, nor any of their contractors, subcontractors, or their employees, makes any warranty, express or implied, or assumes any legal liability or responsibility for the accuracy, completeness or usefulness of any information, apparatus, product or process disclosed, or represents that its use would not infringe privately owned rights.

The views. opinions and conclusions contained in this report are those of the contractor and do not necessarily represent those of the United States Government or the United States Department of Energy.

\author{
PACIFIC NORTHWEST LABORATORY \\ operated by \\ BATTELLE \\ for the \\ UNITED STATES DEPARTMENT OF ENERGY \\ Under Contract DE-AC06-76RLO 1830
}

\author{
Printed in the United States of America \\ Available from \\ National Technical Information Service \\ United States Department of Commerce \\ 5285 Port Royal Road \\ Springfield, Virginia 22151
}

Price: Printed Copy $\mathbf{s}$ $\because$ Microfiche $\$ 3.00$

NTIS

*Pages Selling Price

$001-025 \quad 54.00$

$026-050 \quad \$ 4.50$

051-075 \$5.25

076-100 $\$ 6.00$

101-125 \$6.50

126. $150 \quad \$ 7.25$

151-175 $\$ 8.00$

$176-200 \quad \$ 9.00$

201-225 $\$ 9.25$

$226-250 \quad \$ 9.50$

251-275 \$10.75

$276-300 \quad \$ 11.00$ 
AN ASSESSMENT OF ENVIRONMENTAL

HEALTH AND SAFETY ISSUES

ASSOCIATED WITH THE

COMMERC IAL IZATION OF

UNCONVENTIONAL GAS RECOVERY:

DEVONIAN SHALE

PNL Project Manager

E. F. Riedel

DOE Project Manager

G. J. Rotariu

Office of Environmental Programs

September 1981

Prepared for the

U. S. Department of Energy

under Contract DE-AC06-76RLO 1830

Pacific Northwest Laboratory

Richland, Washington 99352 


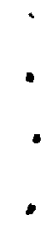




\section{CONTENTS}

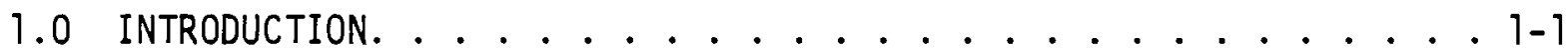

2.0 RESOURCE DESCRIPTION AND THE EASTERN GAS SHALES PROJECT . . . . . 1

2.1 ORIGIN . . . . . . . . . . . . . 2-2

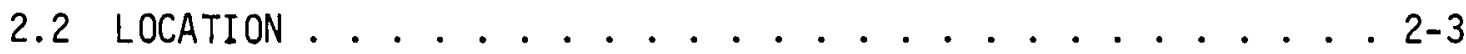

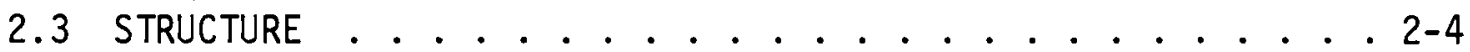

2.4 RESOURCE SIZE. . . . . . . . . . . . . 2-5

2.5 EASTERN GAS SHALES PROJECT . . . . . . . . . . 2-5

3.0 DEVONIAN SHALE TECHNOLOGY .....................

3.1 EXPLORATION. . . . . . . . . . . . . . . . 3-4

3.1.1 Resource Characterization ......... 3-4

3.1.2 Remote Sensing. . . . . . . . . . . 3-5

3.2 STIMULATION METHODS. . . . . . . . . . . . . . . . . . .

3.2.1 Borehole Shooting ........... . . 3-7

3.2.2 Chemical Explosive Fracturing . . . . . . . 3-7

3.2.3 Hydraulic Stimulation ............ 3-8

3.2.3.1 Massive Hydraulic Fracturing . . . . . 3-11

3.2.3.2 Foam Fracturing. . . . . . . . . . 3-11

3.2.3.3 Cryogenic Fracturing . . . . . . 3-12

3.2.3.4 Dendritic Fracturing . . . . . . . . 3-14

3.2.4 Directional Drilling. . . . . . . . . . 3-15

4.0 ASSESSMENT OF ENV IRONMENTAL, HEALTH AND SAFETY IMPACTS. . . . . . 4-1

4.1 DESCRIPTION OF DEVONIAN SHALE ENVIRONMENT. . . . . . . . 4-1

4.2 ENVIRONMENTAL ASSESSMENT . . . . . . . . . . . 4-2

4.2.1 Exploration ............... 4-5 
4.2.2 Field Development .............. 4-5

4.2.2.1 Construction of Roads. . . . . . . . 4-6

4.2.2.2 Construction of Pipeline ........ . 4-7

4.2.2.3 Drilling of Production Wells ....... 4-7

4.2.2.4 Construction of Distribution and
Treatment Facilities........... 4- . . . .

4.2.2.5 Stimulation of Production We1ls..... 4-10

4.2.3 Production. ................. 4- . . . . .

4.2.4 Abandonment................. . . . . . . . .

4.3 HEALTH AND SAFETY ASSESSMENT . . . . . . . . . . . 4-13

4.3.1 Noise....................... . . . . . . . .

4.3.2 Air Pollution................ . . . . . . . .

4.3.3 Accidents ................ . . . . . . . . . .

5.0 CONCLUSIONS AND RECOMMENDATIONS .............. . . . . . .

APPENDIX A - PETROLEUM FIELD TECHNOLOGY. . . . . . . . . . A-1

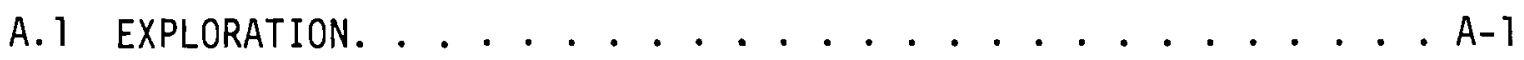

A.1.1 Regional Surveys. . . . . . . . . . A-2

A.1.2 Detailed Surveys. . . . . . . . . . A-2

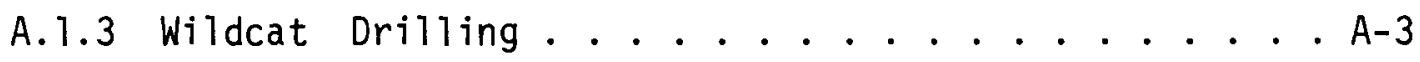

A.2 FIELD DEVELOPMENT. . . . . . . . . . . . . . . . A-4

A.2.1 Site Preparation. ............... A-4

A.2.2 Drilling. ................. . . . .

A.2.3 Completion. . . . . . . . . . . . A-7

A.2.4 Well Testing. . . . . . . . . . . . A-7

A.3 PRODUCTION . . . . . . . . . . . . . . A-7

A.4 ABANDONMENT. . . . . . . . . . . . . . . A-7 
APPENDIX B - BARRIERS TO COMMERCIAL PRODUCTION. . . . . . . . . B-1

B. 1 RISK CAPITAL AVAILABILITY . . . . . . . . . . B-1

B.2 Legal CONStRaints . . . . . . . . . . . . . B-2

B.3 TECHNOLOGICAL PROBLEMS ASSOCIATED WITH EXPLOITATION OF DEVONIAN SHALE. .......... B-3

B.4 PiPeline AVAILABILITY . . . . . . . . . . B-4

B.5 LACK OF DRILL RIGS. . . . . . . . . . . . B-4 APPENDIX C - GLOSSARY OF TERMS. ................. . . . REFERENCES. .......................... . . . . . 
$\cdot$
$\cdot$
$\cdot$ 


\section{$\underline{\text { FIGURES }}$}

2.1 America's Potential Gas Supply. . . . . . . . . . . 2-1

2.2 Appalachian, Illinois and Michigan Basins ......... 2-3

2.3 Model of Macrofracturing . . . . . . . . . . . 2-5

3.1 Equipment Types and Location During an MHF Job. . . . . . . . 3-10

3.2 Schematic for Foam Fracturing Equipment Layout. . . . . . . . 3-12

3.3 Dentritic Fracturing Pattern of the Kiel Process. . . . . . . . . 3-15

3.4 Deviated Wells and Earth Fracture System. . . . . . . . . 3-16

4.1 Decibel Levels and Verbal Loudness Descriptions of Various Sounds ................ . 4-15

4.2 Relationship Between CO Exposure (Hours and Concentration) and Health Effects................ . 4- . . . . . .

A.1 Rotary Drilling Rigs. . . . . . . . . . . . . A-5

A.2 Casing Strings and Pipe Used in an $0 i 1$ Well . . . . . . A-6

A.3 Two-Phase Separator . . . . . . . . . . . . A-8

B.1 Gas Pipeline Capacities in the U. S. . . . . . . . B B-5 


\section{$\underline{\text { TABLES }}$}

3.1 States in the Recovery of Petroleum from Reservoirs. . . . . . 3-1

3.2 Petroleum Recovery Operations for Major

Onshore Petroleum Resources. . . . . . . . . . . . 3-2

3.3 Summary Description of Activities Common to All Resources. . . . 3-3

3.4 Technical Job Specifications for a FF Service. . . . . . . . 3-13

4.1 Comparisons of Potential Environmental Impacts from Gas Field Development. . . . . . . . . . . . 4-3

4.2 Applicable Federal Environmental, Health and Safety Regulations. . 4-4

4.3 Emissions from One 1100-hp Diesel Engine Using "Diese1" Fuel . . 4-9

4.4 Emissions from a Typical Stimulation Job Using Three 1100-hp Diesel Engines Burning "Diese1" Fue1 . . . . . . . . . . . 4-11

4.5 Permissible Noise Exposures in the Workplace . . . . . . . . 4-14

4.6 Summary of Noise Levels Identified as Requisite to Protect Public Health and Welfare with an Adequate Margin of Safety . . . . 4-16

4.7 Summary of Fatal Injuries in the Petroleum Industry, 1974 to 1979. 4-19

4.8 Summary of Occupational Injuries in the Petroleum Industry,

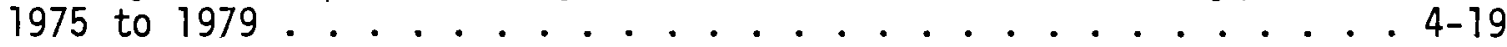

4.9 Summary of Occupational Injuries and Fatalities in Devonian Shale Gas Production in the Year 2000 . . . . . . . 4-20

A.1 Stages in the Recovery of Petroleum for Reservoirs . . . . . A-2 


\section{,}




\subsection{INTRODUCTION}

The United States is in the midst of a domestic fue 1 shortage. The need for more energy sources has forced the United States to develop and implement new techniques for identifying and increasing the recovery of our fossil energy resources.

Natural gas continues to provide one-quarter of all the energy used in the United States. Recovering natural gas from unconventional sources is of major importance in our overall energy program. Four large unconventional gas resources have been identified as having significant potential for development and positive impact on future gas supplies. The four resources and projects directed at recovery of each of these resource areas are:

\section{Sources}

Tight gas sands

Methane associated with coal seams

Devonian age shale

Methane contained in geopressured aquifers
Projects

Western gas sands

Methane from coal

Eastern gas shales

Geopressured aquifers

Research in three of the resource areas is conducted by the Office of Environmental Programs, U. S. Department of Energy. The fourth, geopressures aquifers, is part of the Department's geothermal energy program.

The current administration is focusing the unconventional gas recovery programs toward activities that may involve long-range goals, high risks, and/or new technologies. The $0 i 1$ and Gas Program plans to encourage new, enhanced and marginal oil and gas production by assisting private industry through technical guidance and support together with opening previously restricted or closed areas for petroleum exploration. These incentives plus such economic incentives as the decontrol of domestic oil prices, and the trend toward further deregulation of natural gas prices, are aimed at encouraging private industry to develop more domestic fuel sources. 
Before these unconventional natural gas sources can add significantly to our nation's supply, the public health and safety, environmental, social, economic and legal/political consequences and constraints that may be associated with these technologies must be identified and examined.

The purpose of this study is to identify and examine potential public health and safety issues and the potential environmental impacts from recovery of natural gas from Devonian age shale. This document will serve as background data and information for planners within the government to assist in development of our new energy technologies in a timely and environmentally sound manner. This assessment is being conducted for the Office of Environmental-Programs, U. S. Department of Energy. This Office is responsible for assessing all potential environmental, health and safety consequences and constraints of any new technology for producing energy. These assessments provide the basic reference information to be used in the preparation of Environmental Development Plans (EDPs) and Environmental Readiness Documents (ERDs). In addition they can also be used for the preparation of Project Environmental Plans (PEPs), site specific Environmental Assessments (EAs) and for site specific Environmental Impact Statements (EISS). These assessments may also be used in the development of policy and the formulation and implementation of Research and Development (R\&D) plans.

Gas has been produced from the Devonian age shale for a long time. It has, however, never been a major contributor to our overall natural gas reserves. Its proximity to large industrial gas users in the eastern part of the Unites States suggests that more production from this resource would be beneficial. In the future this resource may become a more important part of our nation's energy supply.

This report represents the fourth in a series of four reports on unconventional gas. Three previous studies assessed the potential environmental, health and safety impacts from recovery of natural gas from Tight Western Sands (Riedel et al. 1980); Methane from Coal Seams (Ethridge et al. 
1980); and Geopressured Aquifiers (A. Usibelli et a1. 1981). The latter study was performed at the Lawrence Berkeley Laboratory under the program guidance of PNL. A general background on all four areas of unconventional gas is summarized in Potential Barriers to Increased Production of Natural Gas from Unconventional Sources (Riede1, Rotariu, and Goldberg 1980).

This report describes the resource and the DOE eastern gas shales project in Section 2. Section 3 describes the new and developing recovery technologies associated with Devonian shale. An assessment of the environmental, health and safety impacts associated with a typical field is presented in Section 4. The "typical" field for this assessment occupies ten square miles and is developed on a 40 -acre spacing (that is, there is a well in each 40 -acre grid). This field thus has a total of 160 wells. Finally, Section 5 presents the conclusions and recommendations. A reference list is provided to give a greater overview of the technology. Appendix A contains a generic description of all the activities associated with the exploration and exploitation of petroleum. Other barriers which may be important to the commercialization of this resource are presented in Appendix B. Appendix $C$ is a glossary of some of the more important terms used in the petroleum industry.

Recovery of gas from eastern gas shales is still in the developmental stages and some of the techniques and constraints described in this report may not apply in the future or in the final commercially-scaled projects. The material described in this report is representative of the state-ofthe-art as reflected by governmental and industrial publications and contacts as of early-winter 1980. 


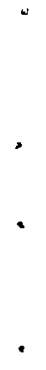




\subsection{RESOURCE DESCRIPTION AND THE EASTERN GAS SHALES PROJECT}

Vast quantities of very high quality (up to 1500 British thermal units per cubic feet $\left[\mathrm{Btu} / \mathrm{ft}^{3}\right]$ ) natural gas are contained in shale deposited during the late Devonian and early Mississippian eras. This gas is recoverable and can be added to the existing reserves to complement our more conventional natural gas supplies. The potential natural gas recoverable from all onshore and offshore sources is shown in Figure 2.1. Current proven reserves are approximately 200 trillion cubic feet (TCF). This is about a ten-year supply at current usage. Devonian shale is the largest of the unconventional resources. Devonian shale is estimated to contain 903 TCF of natural gas. This would supply current gas needs for about 45 years. Devonian shale thus may represent one of the most important of our unconventional natural gas resources.

\section{MAXIMUM ESTIMATED RESERVES AND YEARS OF SUPPLY}

\section{Gas Produced Since \\ Initial Discovery \\ 1821.1978 CUMULATIVE \\ 573 TCF \\ Currently Producing 200 TCF - 10 YEARS \\ Gas from Coal Seams 250 TCF - 13 YEARS \\ Geopressured Brines 256 TCF - 13 YEARS \\ Western Tight Sands 300 TCF - 15 YEARS \\ Devonian Shale 903 TCF - 45 YEARS}

1 TCF (one trillion cubic feet) will supply 100,000 homes for 84 years.

Life span assumes that current consumption remains constant

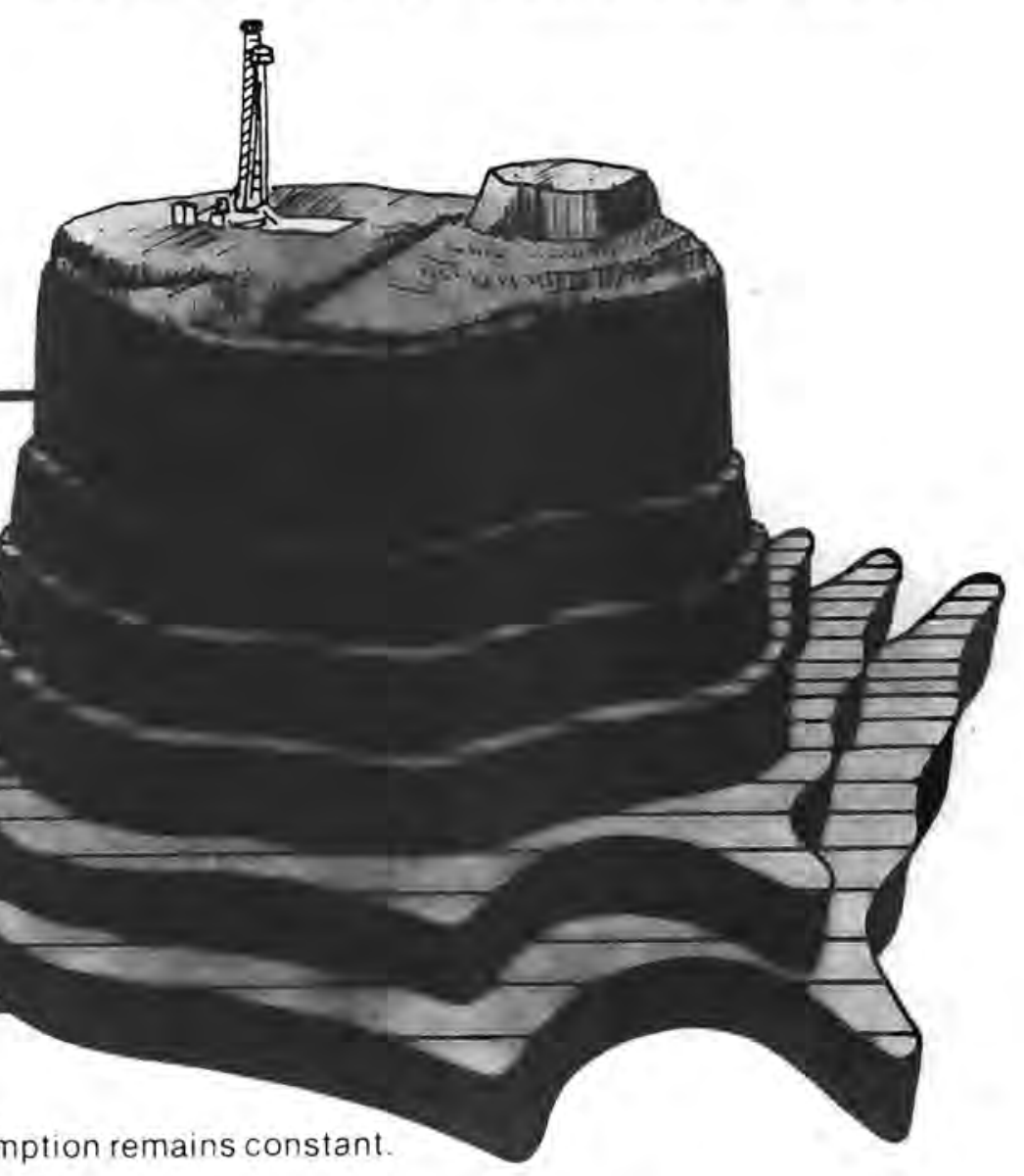

FIGURE 2.1 America's Potential Gas Supply (Journal of Petroleum Technology 1981) 
The principal distinction between gas from unconventional sources and conventional gas is related to the time required for commercial development. The unconventional resources are only unconventional in the sense that they are not currently undergoing widespread exploitation. Our unconventional resources will become commercially viable when existing economic, environmental, technological, legal and political barriers are overcome. The Department of Energy has identified three unconventional gas resources for commercialization at the present time (Ham and Dewey 1978). These resources are:

- Tight gas sands

- Coalbed methane near local (i.e., non-pipeline) markets

- Devonian shale.

Two additional conventional resources were judged as too uncertain for present commercialization efforts, although both of these resources have active ongoing research projects to facilitate their future commercialization. These resources are geopressured aquifers of the Gulf Coast and coalbed methane (other than for local markets). The amount of gas potentially recoverable from geopressured aquifers may be even more significant than that of Devonian shale, ranging up to 2000 TCF (U.S. Dept. of Energy 1979). However, the uncertainties present in the development of this resource preclude any realistic estimates of recovery of gas from geopressured aquifers at this time. The Department of Energy projects and the resources associated with Devonian Shale are described in this section.

\subsection{ORIGIN}

During the late Devonian period of some 350 million years ago, half of the present continental land mass of the United States was covered by a shallow sea. Erosion of the adjacent 1 ands produced enormous amounts of organic debris and other sediments which were carried into this sea by rivers. The organic debris and other sediments settled out. Where the sites of deposition were in a reducing environment, the organic debris was preserved and formed black mud. In time other sediments gradually covered the black mud. The earth's heat combined with the weight of the overlying sediments and chemical reactions transformed the black mud into a fine grained, laminated sedimentary rock termed shale. 
The same processes that transformed the black mud into shale also produced natural gas. Some of this gas migrated into other porous rock to become conventional gas reservoirs. The remaining natural gas is still contained within the shales.

It is important to note that the Devonian shale is not the same as the oil shale of Colorado, Utah, and Wyoming. The organic matter in the Devonian shale is not the type of kerogen that normally is found in oil shale. Rather, the organic matter in the Devonian shale is similar to coal and is derived primarily from plants (Office of Technology Assessment 1977, p. 23).

\subsection{LOCATION}

Eastern gas shales were deposited long ago in widespread seas west of and marginal to the Appalachian geosyncline. Local names applied to these shales are: Antrim shale, Chattanooga shale, Genesco shale, New Albany shale, and Ohio shale. The shale ranges in thickness from 20 feet in Kentucky to more than 7000 feet in the West Virginia-Virginia border region. It is exposed at the surface in parts of Kentucky, Ohio and Tennessee, but it is also found at depths of from 1500 feet in New York to 5000 feet in Virginia. Gas shale formations underlie much of the Appalachian, Illinois and Michigan Basins (Figure 2.2). These shale deposits have produced gas since the nineteenth

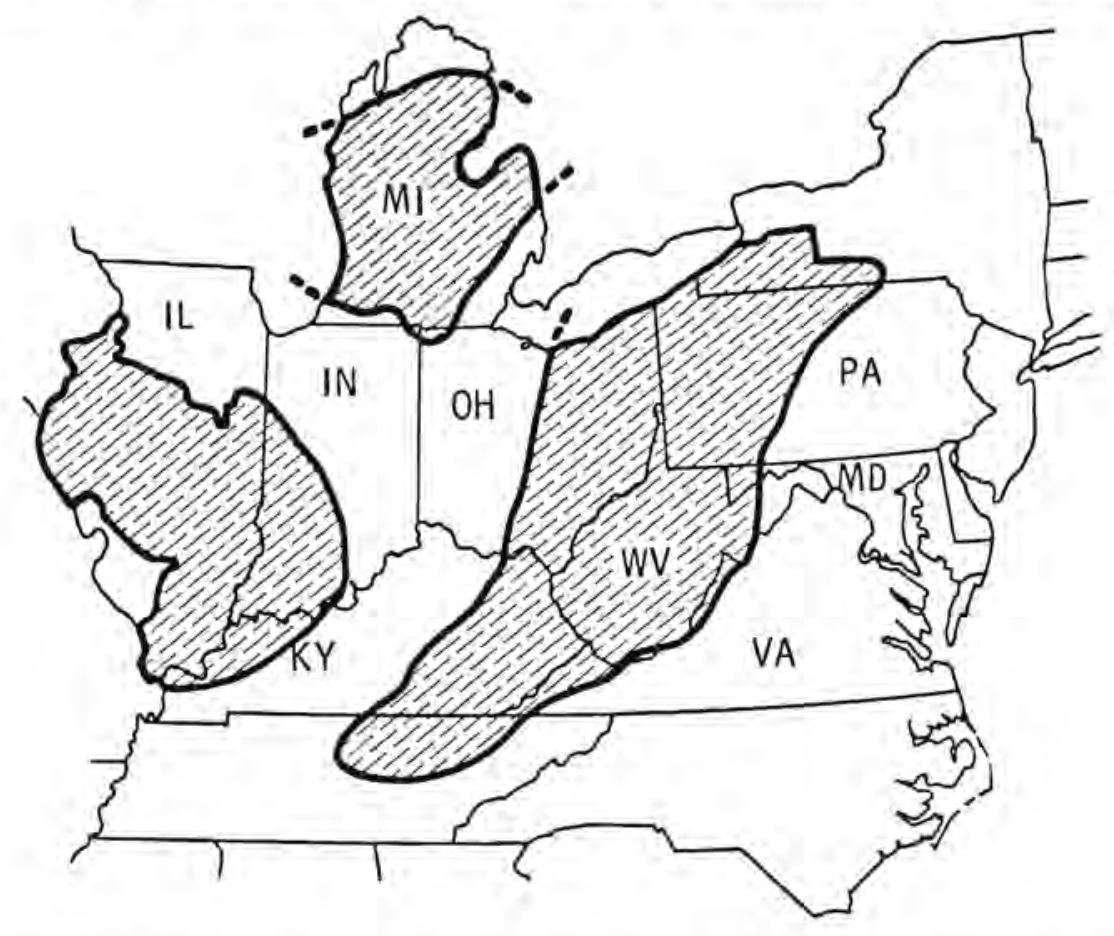

FIGURE 2.2 Appalachian, I1linois and Michigan Basins 
century. A very attractive feature of this resource is its proximity to natural gas markets in the East and Midwest.

The term Devonian shale is commonly applied to all those shales found above the Onandaga or Corniferous 1 imestone and beneath the Berea sandstone. While some of the Devonian shale is really of the Mississippian period, it is normally referred to as Devonian, black, or brown shale. Devonian shale is colored gray, greenish-gray, grayish-brown, brown and black. The dark brown to black portions of the shale possess the most organic material and the greatest potential for finding commercial quantities of natural gas.

A characteristic of Devonian shale is its low porosity and permeability. The pore (or open) space may range from $0.4 \%$ to $4 \%$ of the bulk rock volume. This pore space can be compared to sandstone, which might typically have from $10 \%$ to $20 \%$ pore space. Thus, if a 11 the natural gas were contained in the pore space, an equivalent sized shale reservoir would have less than $40 \%$ of the natural gas contained in an equivalent sized sandstone reservoir. Permeabilities for shales run in the microdarcy range. Shale reservoirs thus have very low flow rates as compared to typical sandstone reservoirs. (SAI, Inc. 1977)

\subsection{STRUCTURE}

A significant aspect of the Devonian shale is its extensive micro- and macrofractures. These fractures account for the majority of the porosity of the shales and thus contain most of the producible natural gas. The remainder of the pore space in the shale is between the mineral grains or crystals. The macrofractures are clearly seen on visual examination of a core sample. The microfractures are very small and are visible only by using a microscope. Most macrofractures are very narrow, on the order of a millimeter or less in width. Spacings of the fractures are variable; however, they do occur close enough together that a six-inch length of a typical core sample may intersect two or more fractures. These macrofractures normally occur in groups that are aligned in a certain direction.

Macrofractures that occur naturally are products of internal stresses and strains in the rock caused by settling of deep-lying faults or other movements within the earth's core. Some of these fractures reach to the surface where they are easily observable. Figure 2.3 shows a model of how this macrofracturing is believed to look. 


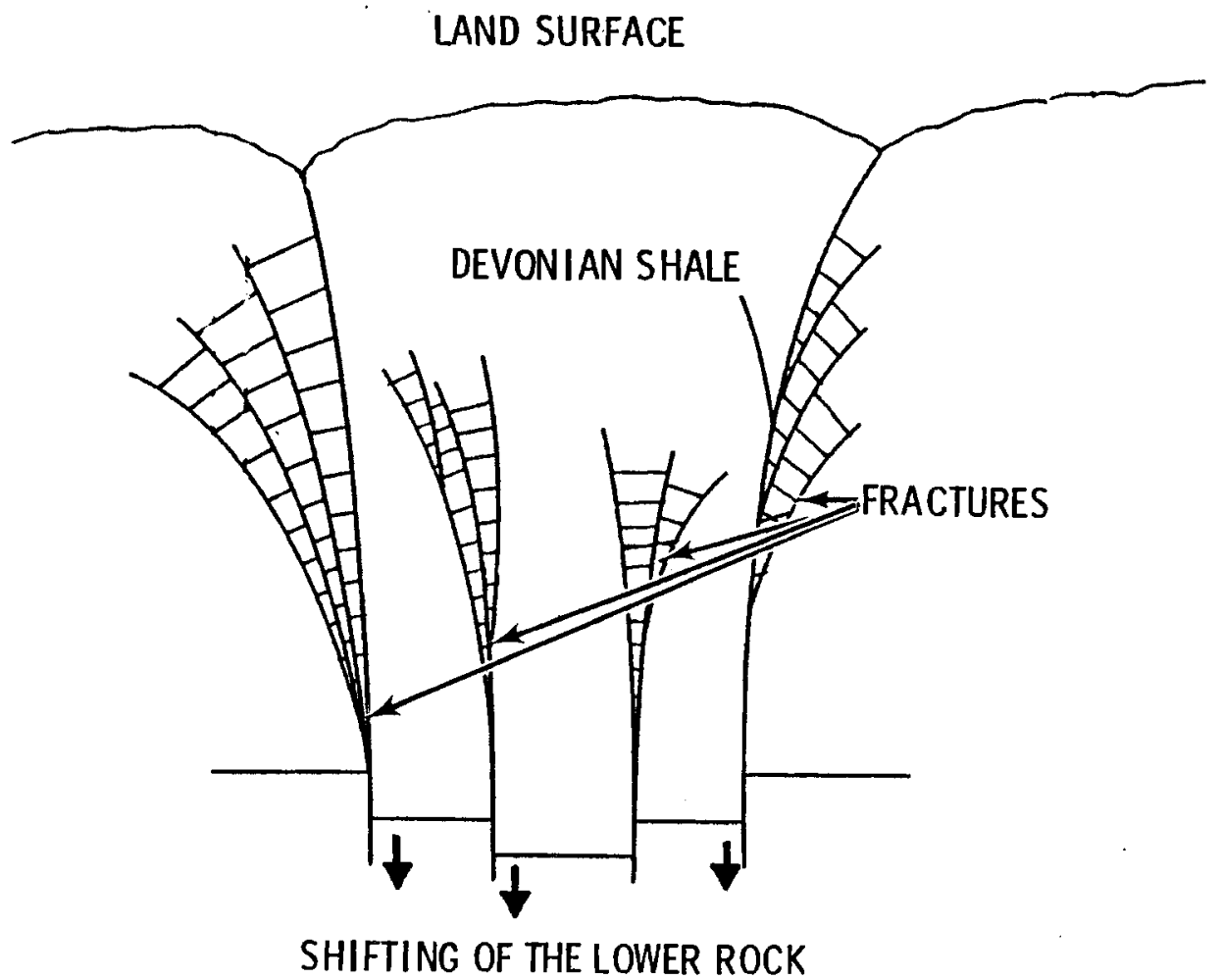

FIGURE 2.3 Model of Macrofracturing

There are at least nine theories which try to explain the cause of macrofracturing (ERDA 1976). Until the cause of fracturing is known, it is difficult to predict where fracture-controlled gas accumulation may be found. Some fractures reach the surface (as illustrated in Figure 2.3) and can be detected by remote-sensing (LANDSAT imagery) techniques.

\subsection{RESOURCE SIZE}

The total gas produced from this resource is estimated to have been 2-5 trillion cubic feet (TCF). Industry estimates of gas-in-place range up to 900 TCF. A government and industry report (U.S. Dept. of Energy 1979, p-18.) estimates the gas-in-place at 500-600 TCF. The rate of production for the resource is estimated to be around 1 TCF per year by 1990. However, the current boom in drilling may result in these estimates being exceeded by as much as a factor of two.

\subsection{EASTERN GAS SHALES PROJECT}

In 1968, when natural gas reserves began to decline, a program was initiated at what is now DOE's Morgantown Energy Technology Center to examine 
marginal gas resources and to determine what methods would be required to extract the large amounts of natural gas trapped in such sources. As a result of this program, the Eastern Gas Shales Project (EGSP) was initiated in 1976 to provide the information and technology base needed to assist the private sector in developing this supply of domestic natural gas. To date, most of the activities within the Devonian shale resource has had government funding. The EGSP is responsible for most of the projects in Devonian shale and is part of the Unconventional Gas Recovery Program. The EGSP is directed towards increasing natural gas production from the Devonian shale of the Appalachian, Illinois, and Michigan Basins of the Eastern United States. The overall goals of the EGSP are to: 1) develop the technologies that will establish effective and environmentally acceptable means for locating and producing natural gas from the Devonian shale, and 2) reduce the uncertainty surrounding the magnitude of the potential reserves so that the private sector will be encouraged to develop the resource on a large scale. Specific elements of this project are:

- Resource Characterization and Inventory

- Extraction Technology Research and Development

- Production Development

- Project Integration.

Activities in the resource characterization and inventory element are directed at the estimation of total and recoverable gas reserves, and the development and application of geological, geochemical and geophysical methods to identify analogs to known fracture systems and production areas in an attempt to locate unknown fractured systems. Results from this element will be discussed in greater detail in the next section. Projects in the area of extraction technology are attempting to develop a comprehensive understanding of the factors are attempting to develop a comprehensive understanding of the factors affecting gas production from reservoirs in various geologic regions. These projects are also concentrating on the development of forecasting capabilities to predict which stimulation method will yield the best result within a given geologic condition. Results from this research are reviewed in greater detail in the next section.

The goals of the production development element are to: test, evaluate, and document exploration techniques used to locate natural fracture systems in the Devonian shale; verify and document the different extraction techniques 
used to maximize the recovery of natural gas; and establish economically feasible options for exploration, drilling, completion, and stimulation techniques in view of current and projected exploration and extraction technologies. The project integration activities seek to provide direction and guidance for meeting project goals and objectives from an overall systems perspective. 


\subsection{DEVONIAN SHALE TECHNOLOGY}

New technologies associated with the recovery of natural gas from Devonian shale resources are described in this section. Many of the operations associated with the exploration and exploitation of natural gas from Devonian shale are identical with conventional petroleum recovery practices, which are discussed in Appendix A. These technology descriptions provide a basis for identifying and evaluating the potential environmental, health and safety issues related to the commercial utilization of this resource. These issues are discussed in Section 4.

The general stages in the recovery of petroleum from reservoirs are summarized in Table 3.1. Table 3.2 presents a brief comparative description

TABLE 3.1. Stages in the Recovery of Petroleum from Reservoirs

1. EXPLORATION

- Regional Surveys

- Detailed Surveys

- Wildcat Drilling (and Stimulation)

2. FIELD DEVELOPMENT

- Reservoir Definition (Well Drilling and Stimulation)

- Planning Well Space and Location

- Drilling Wells

- Installation of Treating Facilities

- Collection and Distribution Facilities

3. PRODUCTION

- Surface Facilities Maintenance

- We1r Maintenance

4. ABANDONMENT

- Plug Wells (cement to surface) and Mark

- Remove Surface Facilities

- Recontour and Reseed Well Sites and Lease Roads 


\section{TABLE 3.2. Petroleum Recovery Operations for Major}

Onshore Petroleum Resources

\begin{tabular}{|c|c|c|c|c|c|c|}
\hline Compar ison ractors & Typical Onshore ofl field . & Typtcal Onshore Gas Fteld & Devontan shale & I Ight Western Sands .... & Codl Bed Methane & Geopressured Anutfers \\
\hline 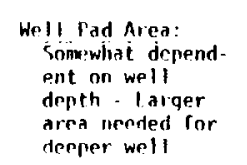 & 1 to 2 acres $/ 10.000 \mathrm{ft}$ & 2 to 5 acres $/ 10,000 \mathrm{ft}$ & 1 acre/5. $1110 \mathrm{ft}$ & 3 to 6 acres $/ 10.000 \mathrm{ft}$. & $1 / 2-1$ acre $/ 1,00 n$ ft & 1 to 2 acre $/ 10,000 \mathrm{ft}$ \\
\hline $\begin{array}{l}\text { Coumon Hell } \\
\text { Spacing }\end{array}$ & 40 arres $/ 10,000 \mathrm{ft}$ & $\begin{array}{l}640 / 10,000 \mathrm{ft} \\
160 / 5.000 \mathrm{ft}\end{array}$ & 40 acres & 640 acres $/ 10,000 \mathrm{ft}$ & Ulinknown & Unknown \\
\hline $\begin{array}{l}\text { Wndl completion } \\
\text { Activitics }\end{array}$ & $\begin{array}{l}\text { 1. Isolate zone(s) of interest } \\
\text { by setting a packer. } \\
\text { 2. Cement casing across zone. } \\
\text { 3. Perforate } 11 \text { to } 2 \text { shots } 4 \text { foot. } \\
\text { 1. Run small acid jot. }\end{array}$ & $\begin{array}{l}\text { 1. Isolate zone(s) of interest } \\
\text { by setting o packer. } \\
\text { 2. Cement casing across zone. } \\
\text { 3. Perforate-1 shot/ } / \mathrm{ft} \text { to } 1 \\
\text { shot/25 ft. } \\
\text { 4. Run small acid job. } \\
\text { 5. Run frac job. }\end{array}$ & $\begin{array}{l}\text { 1. Isolate zone(s) of interest } \\
\text { by setting a packer. } \\
\text { 2. Cement casing across zone. } \\
\text { 3. Perforate I shot/ft to } 1 \\
\text { shot/25 } \mathrm{ft} \text {. } \\
\text { 4. Run small acid/frac fol. } \\
\text { 5. Rum foam frar. job. }\end{array}$ & $\begin{array}{l}\text { 1. Isolate zone(s) of interest } \\
\text { by seting a packer. } \\
\text { 2. Cement casing across zone. } \\
\text { 3. Perforate } 1 \text { shot/ft to I } \\
\text { shot/75 } \mathrm{t} \text {. } \\
\text { 4. Run small acid job. }\end{array}$ & $\begin{array}{l}\text { 1. Several procedures only nne } \\
\text { of which resentles the pre- } \\
\text { cedting ones. Hore common is } \\
\text { to drill lave vert fal hole } \\
\text { and dril horlzoutt hol hes } \\
\text { outward from this. Holes } \\
\text { are not cased and perforated. }\end{array}$ & $\begin{array}{l}\text { 1. Isolate zone(s) of Interest } \\
\text { by setting a parker. } \\
\text { 2. Cenent casing across zone. } \\
\text { 3. Perforate I shot/ft. }\end{array}$ \\
\hline $\begin{array}{l}\text { Production } \\
\text { opcrations }\end{array}$ & $\begin{array}{l}\text { 1. Electrical pump in operation. } \\
\text { 2. Three phase separator. } \\
\text { 3. May have large amounts of } \\
\text { brine to be disposed of. } \\
\text { 4. Oil is pipelined or trucked. } \\
\text { 5. Gas (ad is pipelined (may } \\
\text { need compressor station). } \\
\text { 6. Hork area is } 400 \text { sq. It. } \\
\text { 7. Central processing area is } \\
\text { 25 arres. }\end{array}$ & $\begin{array}{l}\text { 1. No pumin. } \\
\text { 2. Three phase separator. } \\
\text { 3. Very limt ted brine production } \\
\text { 4. Condegpate is trucked. } \\
\text { 5. Gas is is pirelined. } \\
\text { 6. Work area is about i acre. } \\
\text { 7. Gas compressor station (if } \\
\text { needed) may occupy } 2-5 \text { acres. }\end{array}$ & 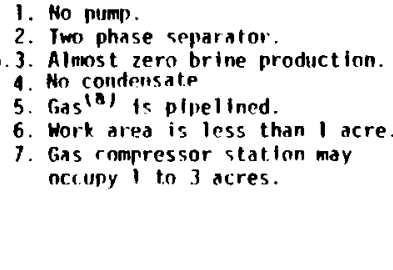 & 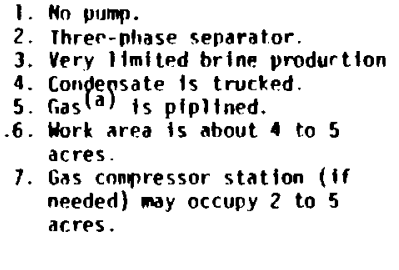 & 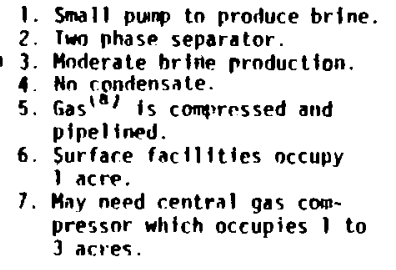 & 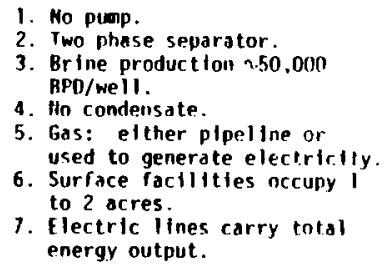 \\
\hline Production life & $\begin{array}{l}\text { 1. Prinary } 0 \text { to } 5 \text { years. } \\
\text { 2. Materficod io to is years. } \\
\text { 3. Tertiary } 10 \text { to } 40 \text { years. }\end{array}$ & 1. Primary 0.5 to 20 years. & 1. Primary 950 years. & 1. Primary 9.5 to 20 years. & 1. Primary 1 to 7 years. & 1. Unknown. \\
\hline 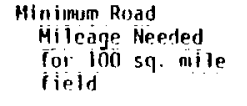 & 380 miles & 175 miles & 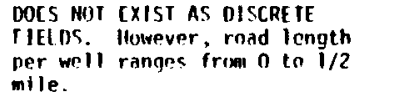 & 175 miles & $\begin{array}{l}\text { Not developed os discrete } \\
\text { fields Road length averages } \\
\text { ahout } i / 2 \text { mile per well. }\end{array}$ & No data \\
\hline Ownership of lands & 1. Federal and private. & 1. Federal and private. & 1. Hainly private. & 1. Hostly federal. & 1. Mainly private. & 1. Mainly \\
\hline
\end{tabular}

(a) Gas at this stage still contains the natural gas liquids (NGit) mainly ethane and propane. The NGL may be extracted and trucked to market or
the MGI may be left in. 
of the petroleum recovery operations for the major onshore petroleum resources, both conventional and unconventional. Key differences in these operations are presented in the table. For example, the well pad for Devonian shale recovery operations is about one acre in area compared to the two to five acres required for a typical onshore gas field. Taking another example, most of the land containing Devonian shale resources is in private ownership while conventional recovery of gas and oil takes place on federally-owned land. The activities of exploration, drilling and site restoration are virtually identical for all resources. Activities in these operations are summarized in Table 3.3.

Table 3.2 also shows that substantial differences between conventional practices and recovery operations in Devonian shale occur during the exploration and stimulation steps. The technologies associated with these two steps are discussed in depth in this section. A third practice, which is different from most conventional practices, is the drilling of deviated wells that intersect the shale horizontally. Since this procedure partially substitutes for well stimulation, it will also be discussed in the subsection on stimulation.

\section{TABLE 3.3 Summary Description of Activities Common to All Resources}

\begin{tabular}{|c|c|}
\hline Activity & \\
\hline Exploration & $\begin{array}{l}\text { Identical for all oil and gas work. Major emphasis is on } \\
\text { better resolution of seismic data and the building of more } \\
\text { sensitive instruments. }\end{array}$ \\
\hline Drilling & $\begin{array}{l}\text { Site and depth specific. Rigs come in small }-5,000 \mathrm{ft} \\
\text { capability, medium } 25,000 \text { to } 15,000 \text { ft capabilities and } \\
\text { large } ~ \text { over } 15,000 \text { ft capabilities. In addition, very } \\
\text { shallow wells, less than } 1,000 \mathrm{ft} \text {, may be drilled with } \\
\text { water well rigs. We } 11 \text { drilling operations can vary consid- } \\
\text { erably depending on the conditions encountered. High } \\
\text { formation pressures require the use of heavy weight mud } \\
\text { drilling. This slows the drilling rate. Low formation } \\
\text { pressures typically encountered in gas drilling enable low } \\
\text { weight mud drilling to be used. This results in drilling } \\
\text { rates around ten times the normal rate. Drilling rates are } \\
\text { also slowed when very hard zones are encountered, but can be } \\
\text { increased substantially in very soft zones. lihen potable } \\
\text { water is encountered, casing must be set and cemented. Tivo } \\
\text { complete trips of the drill string require a core sample } \\
\text { to be taken. Both of these operations slow overall drilling } \\
\text { time. }\end{array}$ \\
\hline Site Restoration & $\begin{array}{l}\text { Return to original use. May require recontouring and } \\
\text { reseeding. }\end{array}$ \\
\hline
\end{tabular}


There are several technologies for exploration and stimulation which exhibit potential commercial viability. The effectiveness of a number of different technologies is currently under study. Since these stimulation and recovery technologies are in a state of flux, all viable alternatives are discussed in this assessment.

\subsection{EXPLORATION}

Exploration includes all of the geological, geochemical and geophysical techniques used for locating geological traps that may contain petroleum resources. Commercial quantities of natural gas are found where a large number of natural fractures occur. Special techniques are needed for finding natural gas within the Devonian shale resource since fractures in the shale cannot be located by current technologies. The only successful method currently available for locating gas wells within the Devonian shale is through drilling. At the present time, there is limited exploration ongoing in the Devonian shale regions. The vast majority of new wells drilled are either step-out or infill wells in known producing areas. Current research has focused on better resource definition and improved remote sensing methods.

\subsubsection{Resource Characterization}

Resource characterization is needed to better define the total gas-in-place in all three major basins and to identify potential new exploration methods that can be used for locating commercial gas deposits. Major factors that affect gas production are bed thickness, organic content, porosity, permeability and of special importance for Devonian shale, fracture intensity and continuity.

New geological maps are available for all three of the basins. These maps delineate the type, thickness and depth of the different shale deposits. They are useful for estimating the total gas-in-place but are not useful for locating exact drilling sites since they do not show fracture intensity.

The organic content of Devonian shale is of two types, natural gas and the solid kerogen. The most important organic content is the in-place natural gas. In-place gas has been measured on a large number of cores by sealing them in metal cans and allowing the cores to degas. Selected cores are collected and tested in groups. Mean gas content for all of the core groups tested ranged from 0.003 to 1.110 standard cubic feet (scf) gas per cubic foot (cf) shale and averages about 0.4 scf per cf shale. 
Because most of the natural gas contained in shales is produced through the macrofracture networks (see Figure 2.3), the actual shale porosity and permeability are not constraining production parameters. Typical shale permeabilities are in the milii-to-microdarcy range. Typical porosities range from $0.6 \%$ to $4.0 \%$ (Department of Energy, 1980).

Location of fractures is an important part of developing the Devonian shale resource. One theory currently under investigation is that fractures are related to the structure at the time of deposition. Five wells were drilled on sites located by using this theory. Evidence collected to date supports this theory since natural fractures and gas were present in all five we11s. However, large amounts of water were also present and no significant gas flowed after stimulation.

It is also thought that the pressure from massive glaciers during the last Ice Age caused some of the fracturing within the Devonian shale. Areas in which the Devonian shale overlap massive ice flows are being further examined. One such area borders on Lake Erie, and a number of commercially successful wells have been drilled there.

In summary, the geologic description for these basins is fairly complete. However, no improved exploration rationale for locating gas deposits in Devonian shale has yet emerged from conventional geological and geochemical work.

\subsubsection{Remote Sensing}

Presentiy, there does not appear to be any procedure that can be generaliy used to locate potentially good areas of the Devonian shale for drilling. Two exploration techniques using remote sensing are currently under investigation. The first of these techniques is based on seismic velocity analysis. This procedure (Department of Energy 1980, pp. 3-49) combines three-dimensional seismic sections with downhole seismic shooting. Detailed analysis of seismic velocity data yields information about fractures. This procedure is still untested and its usefulness in locating new gas deposits is unknown.

The second remote sensing technique currently being investigated involves surface mapping, primarily of lineaments, ${ }^{(a)}$ using satellite and aerial

(a) Any line on an aerial photograph. The term is widely applied to lines representing beds, lithologic horizons, unconformities and rock boundaries. 
photography and radar imagery. A promising area of research involves computer enhancement (Wescott and Smith 1979, Howard 1979) and merging of aerial and satellite photographs and radar imagery. It is hoped that the surface lineaments can be correlated with the subsurface fracture networks. This technique has been tried with mixed results. Its ultimate usefulness as an exploration tool is still largely unknown.

\subsection{STIMULATION METHODS}

The previous section discussed methods for selecting drilling sites that may contain commercial quantities of natural gas. However, a typical Devonian shale well after being drilled and completed will have little or no open flow of gas (although an occasional well can have flows of as much as 100 Mscfd). Thus, some method of stimulation must be used to increase flow rates from these wells to commercial levels.

Evaluation of stimulation procedures is very difficult because no two wells are ever the same. This is especially true for the Devonian shale because the chemical and physical properties of the reservoirs vary so much. Various methods are available for stimulation of Devonian shale wells.

Methods that have been tried with some success are:

- Borehole shooting

- Chemical explosive fracturing

- Hydraulic fracturing.

The four types of hydrautic fracturing used are:

- Massive hydraulic fracturing (MHF)

- Foam fracturing (FF)

- Cryogenic fracturing

- Dendritic fracturing.

Each of these techniques is discussed below. An additional procedure, that of directional drilling, is also considered because it can be used in place of one of the other stimulation methods. 


\subsubsection{Borehole Shooting}

The traditional stimulation method used for Devonian shale wells is borehole shooting. This method involves the detonation of gelled nitroglycerine in the wellbore over the producing interval. The formation face is physically shattered by the explosion. When the rubble is removed from the hole, the enlarged wellbore radius provides better gas movement between the formation and the wellbore.

Wellbore shooting is a relatively inefficient stimulation technique because it has very limited radial effect. Also since not all areas of shale are gas producers, a large part of the explosive energy is wasted. It is, however, relatively inexpensive and can be (and is) profitable in Devonian shale wells with favorable geologic conditions. This technique is currently less popular than hydraulic stimulation, which is typically more effective.

\subsubsection{Chemical Explosive Fracturing}

Chemical Explosive Fracturing (CEF) is a procedure in which chemicals are injected into a well under high pressure and forced into the producing formation. When sufficient quantities have been injected, they are detonated. The chemicals, which are non-explosive prior to mixing, include an oxidizer and a hydrazine fuel. They are transported and pumped separately into a wellbore where they combine to form a liquid explosive. As a safety procedure, the liquid explosive can only be exploded downhole. The explosive mixture is forced into natural and induced fractures, and then it is detonated. Upon detonation, the explosion creates secondary fractures which are propped open by the rubble. The explosive mixture which was in the wellibore upon detonation enlarges the wellbore radius. This procedure is intended to increase flow capacity and drainage radius.

The mobile surface equipment used in CEF consists of: a semi-trailermounted oxidizer mix and pump unit, a truck-mounted fuel pump unit, a wellhead assembly operated by remate control, a mobile data-control unit, and a downhole mixer. 
In practice the results of CEF have been poor. The most common problem with the method has been casing failure. CEFs were also tried in conventional sandstone reservoirs in Texas with the same results. In a four-well test in Texas, the results were two failures, one no response and one very slight improvement. Since the majority of the damage occurs in the explosive site, current thought is that exploding material in a deepened well, below the zone of interest, might be successful. However, this hypothesis has not been tested.

\subsubsection{Hydraulic Stimulation}

Hydraulic stimulation has been in use since 1947 (Howard and Fast 1970). It is a process of creating a fracture or a system of fractures in a reservoir via the injection of a fluid under pressure. The fracture is then kept open (propped) by a propping agent which has been added to the fracturing fluid.

Hydraulic stimulation methods which have been used in the Eastern shales are:

- Massive hydraulic fracturing - MHF

- Foam fracturing ( $\mathrm{N}_{2}$ fracturing)

- Cryogenic fracturing $\left(\mathrm{CO}_{2}\right.$ fracturing)

- Dendritic fracturing.

Each of these techniques is discussed in more detail in the following sections. Another stimulation treatment, gas fracturing, was tried in two wells in Kanawtia County, West Virginia. This "gas frac" fluid consisted of methanol, liquefied petroleum gas (mainly propane) and carbon dioxide. While both jobs were very successful, this method is not expected to be used in the near future. Problems in developing safe handling and operating procedures for this fracturing fluid do not appear solvable at this time.

A typical hydraulic fracturing job consists of injecting a proppant and a fracturing fluid. The proppant is normally sand (usually 0ttowa sand) but other solids have been used. Frequently, different types and sizes of proppants are used in the same treatment. The fracturing fluid used in Eastern shales is usually water-based. To the water-base fracturing fluid, chemicals are added that: 
- prevent fluid loss

- increase proppant carrying ability

- produce foam

- stabilize clays

- chealate harmful ions

- break the gel

- prevent friction.

These additives are predominately proprietary. Information on the specific chemicals used is unavailable.

A hydraulic fracturing job consists of a great deal of equipment and a number of different operations or stages. The general layout of the equipment (a)though not all may be required for every job) is shown schematically in

Figure 3.1. The different procedural stages in a hydraulic fracturing job are:

1. Make certain that enough land has been cleared for the necessary equipment.

2. Bring in sufficient tank storage for the job.

3. Bring in sufficient water (or other fluid) for the job.

4. Treat the water as required (add chemicals as needed).

5. Bring in the sand or other proppant material.

6. Bring in the blending and mjxing trucks.

7. Bring in the pumping trucks and crews required.

8. Bring in intensifier trucks for jobs requiring high pressure.

9. Set up for the fracturing job.

10. Run the job.

11. Wait several hours after completing the job for the gel to break down. (a)

12. Flare the well to produce back the fracturing fluid, igniting the flare as soon as the water content is low enough to allow ignition.

13. Remove the crews and equipment.

(a) For $\mathrm{N}_{2}$ or $\mathrm{CO}_{2}$, there is no wait. 


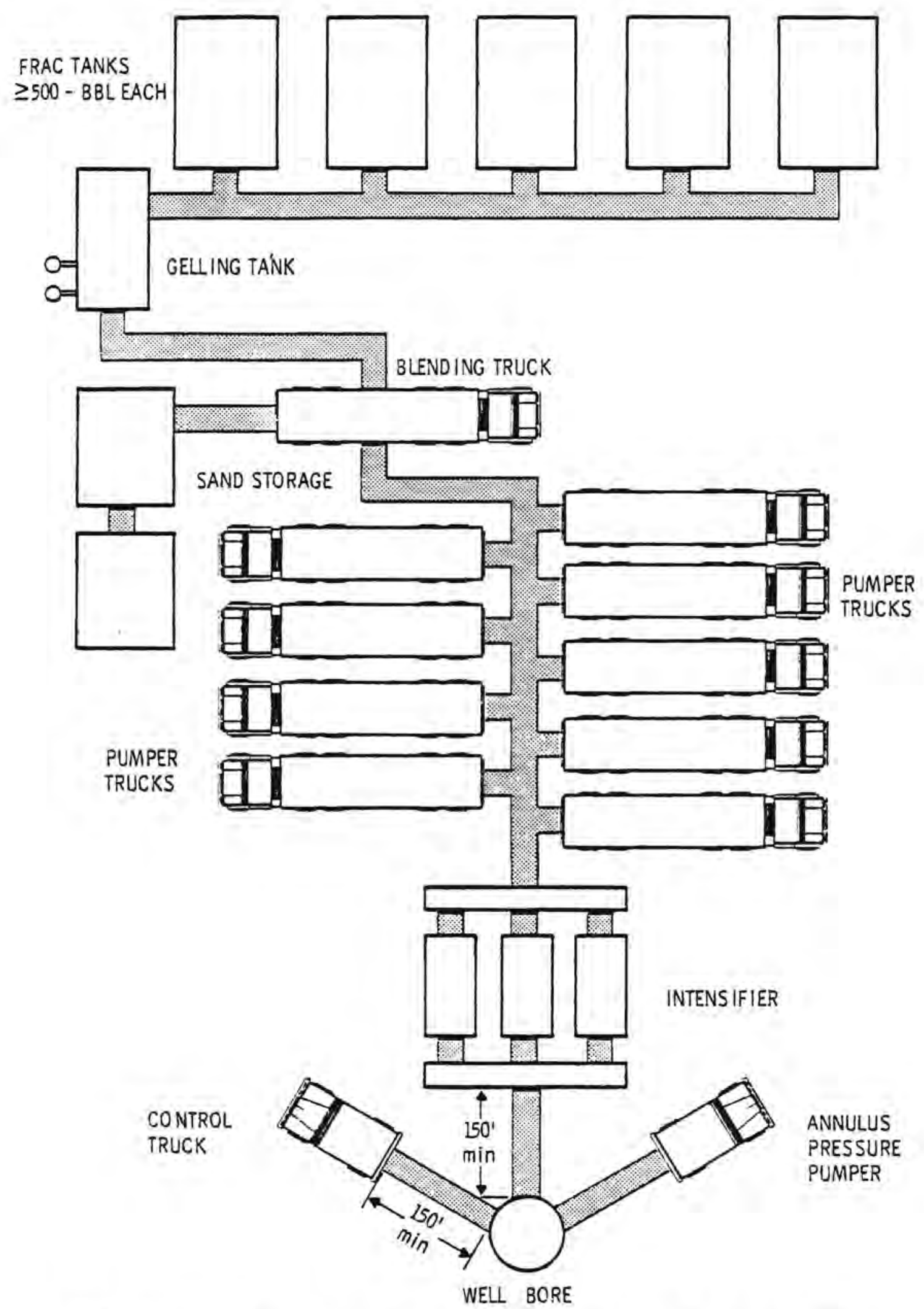

FIGURE 3.1. Equipment Types and Location During an MHF Job 


\subsubsection{Massive Hydraulic Fracturing}

There is no clear definition of what constitutes a massive hydraulic fracturing (MHF) job. There is a constant gradation from very small jobs of a few hundred gallons of fluid to jobs that use more than 2.8 million pounds of proppant and more than a million gallons of fluid. The proppant is added to the fracture fluid to hold or prop the fracture open after the fracturing job is completed. A definition of massive hydraulic fracturing, used by DOE, is any fracture treatment in excess of 300,000 gallons of liquid. Some operators consider any job over 50,000 gallons to be massive.

MHF jobs have not been successful in the Eastern Gas Shales (Cremean 1979) areas. While these jobs have been very successful in Western Gas Sands, the water sensitivity of the shales is apparently responsible for their failure in the East. The water in the fracturing fluid causes most shales to swell and thus lose all their permeability. Thus, this technique is no longer used for the Devonian shale resource.

\subsubsection{Foam Fracturing}

In the foam fracturing (FF) procedure, compressed gas (usually $\mathrm{N}_{2}$ ) and water containing a number of additives, one of which must be a surfactant (a foaming agent), are pumped down the tubing string under sufficiently highpressure to cause formation breakdown and fracturing. Foam fracturing has the advantage over conventional MHF jobs in that very little water is used, water contact time is shorter and the well cleans up much faster. Foam fracturing jobs range in size from very sma 11 to massive jobs. However, since one of the components used in the process is a gas, there are depth limitations due to the fact that pressure increases with depth and foaming decreases with pressure. As a consequence, $\mathrm{FF}$ is normally restricted to formations that are not more than 5,000 to 6,000 feet deep. In a foam fracture, the fluid injected is usually $80 \% \mathrm{~N}_{2}$ and only $20 \%$ water. The intent is to reduce the total water injected, reduce water contact time to minimize clay swelling, and to improve wellbore clean-up using the energy of the $\mathrm{N}_{2}$ gas. As soon as the foam and the proppant have been injected, the well is produced back. The produced fluid is injected into a large storage tank. 
This procedure is currently routinely used and appears to work well. A typical job which may take from one to one-and-a-half hours uses:

- 10 to 20,000 gallons of fluid

- 50 to 100,000 lbs. of sand

$\bullet 1,000,000$ scf of nitrogen.

Figure 3.2 shows the field layout for a foam fracturing job. Table 3.4 summarizes the technical specifications for such a job.

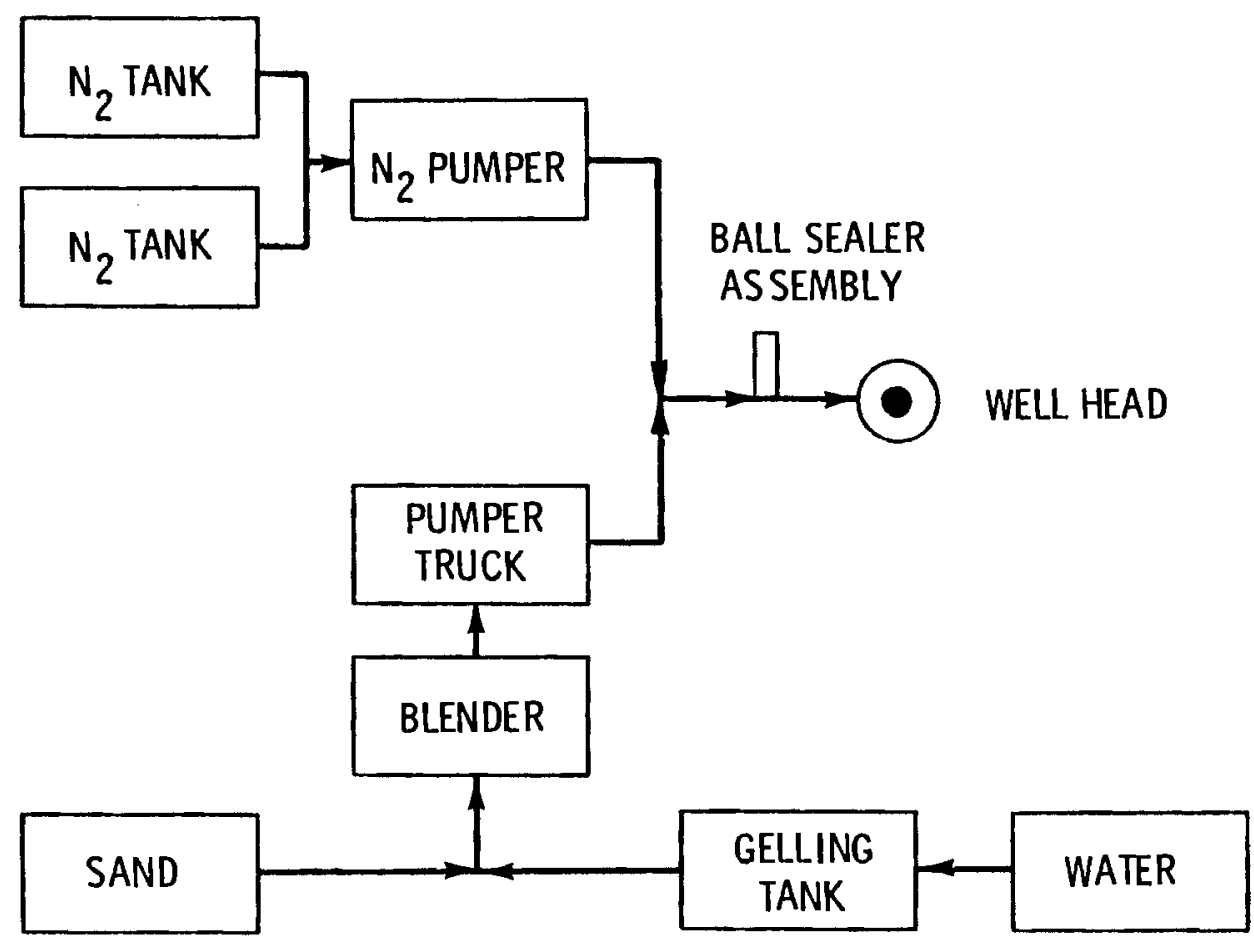

FIGURE 3.2 Schematic for Foam Fracturing Equipment Layout

\subsubsection{Cryogenic Fracturing}

Cryogenic fracturing is very similar to foam fracturing. In this method the injection fluid consists of $25 \% 1$ iquid $\mathrm{CO}_{2}$ with the remainder being water. The $\mathrm{CO}_{2}$ is transported to the fracturing site at low temperature and at the high pressure of 300 psi to keep it liquid. Water is gelled and sand is added. 
TABLE 3.4 Technical Job Specifications for a FF Service (Frohne 1977)

\begin{tabular}{|c|c|}
\hline Parameter & Specification \\
\hline \multicolumn{2}{|l|}{ Basic Job Parameters } \\
\hline Pumping Rate, Foam & $20 \mathrm{bb} 1 / \mathrm{min}$ \\
\hline Pad Volume, Foam & 15,000 ga 1 \\
\hline Treatment Volume, Foam & $148,000 \mathrm{gal}$ \\
\hline Flush Volume, Foam & $5,000 \mathrm{gal}$ \\
\hline Sand & $155,0001 \mathrm{~b}$ \\
\hline \multicolumn{2}{|l|}{ Fracturing Design Parameters } \\
\hline Formation Pressure & 195 psi \\
\hline Formation Temperature & $80^{\circ} \mathrm{F}$ \\
\hline Foam Quality & $75 \% \mathrm{~N}_{2}$ \\
\hline Bottom Hole Total Pressure (BHTP) & 1980 psi \\
\hline Casing & $4-1 / 2$ in. \\
\hline Foam Viscosity, Pipe & $58 \mathrm{cP}$ \\
\hline Friction Loss, Pipe & $10.4 \mathrm{psi} / 100 \mathrm{ft}$ \\
\hline $\mathrm{KCl}$ Concentration, Water & $2 \%$ \\
\hline Foaming Agent Concentration & 5 gal/1000 gal Water \\
\hline \multicolumn{2}{|l|}{ Materials and Equipment Required } \\
\hline Cementer & As Required \\
\hline Pumper & As Required \\
\hline Blender & As Required \\
\hline Foaming Agent & $200 \mathrm{gal}$ \\
\hline $\mathrm{KCl}$ & $8,4001 \mathrm{~b}$ \\
\hline Sand, $20 / 40$ mesh & $155,0001 \mathrm{~b}$ \\
\hline Chemical Diverter & $2,0001 \mathrm{~b}$ \\
\hline Acid, $15 \% \mathrm{HCl}$ & $4,000 \mathrm{gal}$ \\
\hline Acid Inhibitor & As Required \\
\hline Acid Pump & As Required \\
\hline Ball Injector & 1 Unit \\
\hline $\begin{array}{l}\text { Performation Balls, 7/8-in. } \\
\quad \text { diameter }\end{array}$ & 75 \\
\hline
\end{tabular}


This fluid is then mixed with the $\mathrm{CO}_{2}$ at approximately 3,000 psi and injected into the wellbore. Once the fracturing job is completed, the wellhead pressure is released and the $\mathrm{CO}_{2}$ is vaporized. The majority of the injected fluid is then produced back into a surface storage vessel. Both $\mathrm{CO}_{2}$ and $\mathrm{N}_{2}$ fracturing jobs minimize shale-water interaction.

This procedure is currently routinely used and appears to work well. A typical job may take from one to two hours and uses:

$\cdot 20,000$ to 100,000 gallons $\mathrm{CO}_{2}+$ water

- 50,000 to 100,000 pounds of sand.

The decision on whether to use $\mathrm{CO}_{2}$ or $\mathrm{N}_{2}$ in a particular fracture job is not clear. $\mathrm{N}_{2}$ is more readily available but $\mathrm{CO}_{2}$ seems to perform slightly better. The physical layout for a $\mathrm{CO}_{2}$ fracturing job is almost identical to that for an $\mathrm{N}_{2}$ job except $\mathrm{CO}_{2}$ trucks and pumpers replace $\mathrm{N}_{2}$ equipment.

\subsubsection{Dendritic Fracturing}

The preceding methods all produce fractures in a single plane whose orientation is dependent on the overburden pressure. The patented ${ }^{(a)}$ dendritic or Kiel method is designed to propagate fractures much like a tree grows. The concept of dendritic fracturing involves sequential cycles of fluid injection followed by shutting in the well and then allowing the well to backflow. These cycles are designed to fracture the formation and re-direct fracture growth. It is claimed that the in-situ stress field is changed by this sequence so that upon resumption of injection after the pressure drops, a new plane of weakness will fracture and that this new fracture will be perpendicular to the original fracture plane.

Figure 3.3 illustrates the time period sequences of the dendritic fracturing pattern using the Kiel process. These sequences consist of fluid and sand injection followed by the well being shut-in and then back-flowed before the next cycle begins. Proppant is added to optimize fracture conductivity. Fluids used in this method have a minimum of additives and a maximum of gases to promote rapid flowback and cleanup. Field tests in nonshale zones are very optimistic.

(a) United States Patent No. 3,933,205. 
Present data indicate that the natural fracture systems in the Devonian shale are not continuous. Thus, the probability of intersecting random patterns of natural fractures must increase whenever a dendritic-type fracturing job is used. In theory, this should be a very successful stimulation technique. However, before any final conclusion can be reached about this method, it must be tested in Devonian shale zones.

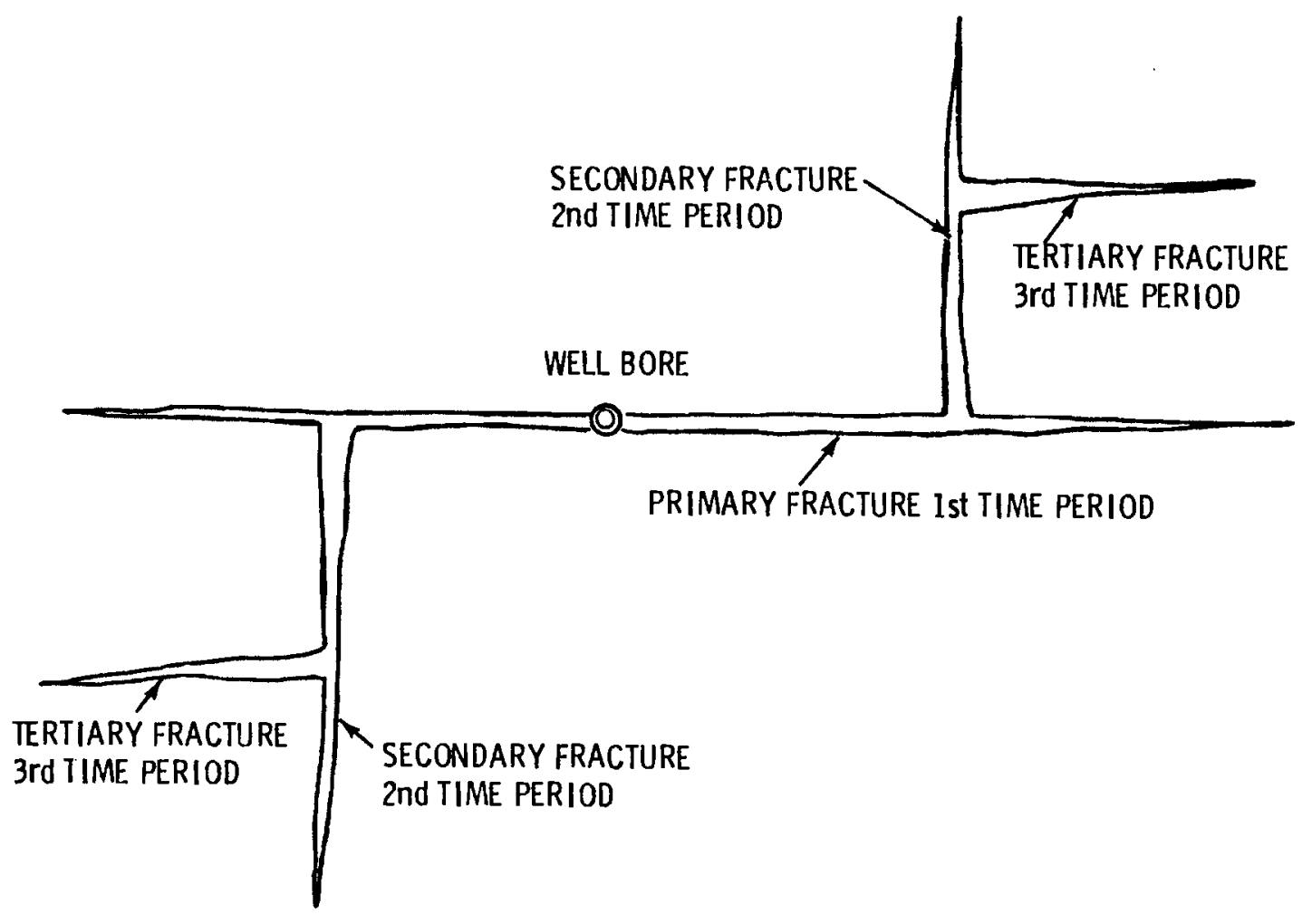

FIGURE 3.3. Dendritic Fracturing Pattern of the Kiel Process

\subsubsection{Directional [rilling}

Directional drilling was originally developed by the petroleum industry to solve some specific problems such as drilling from an offshore platform, reaching locations away from the drill rig, straightening crooked holes and bypassing salt domes. Directional drilling has been successfully done in both Devonian shale and coalbeds. Directional drilling is the process of intentionally drilling a bent hole (see Figure 3.4). Directional drilling 
is expected to work well in the Devonian shale since the intersection with the natural fracture system is enhanced. However, the economic effectiveness of this procedure compared to the other stimulation methods is not currently known.

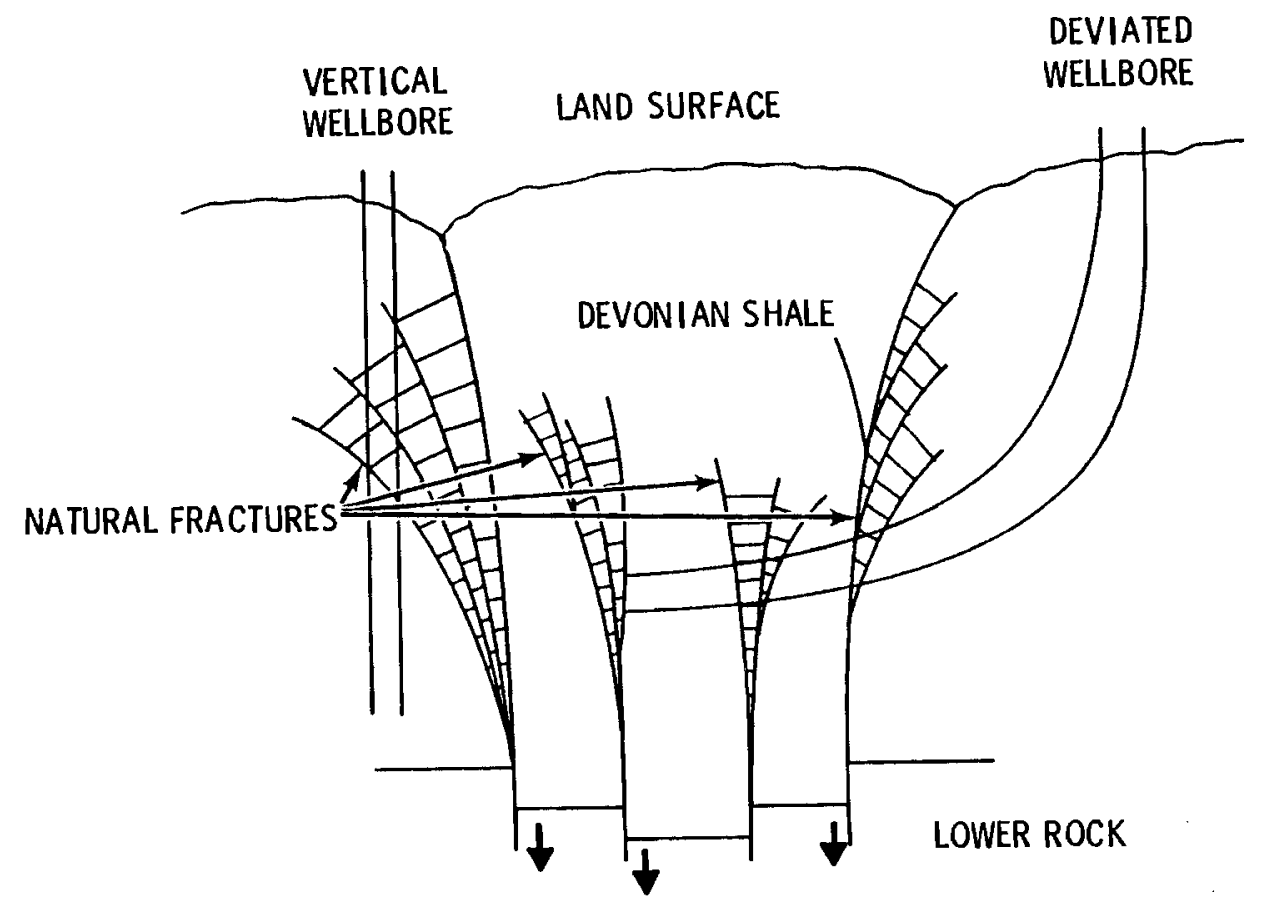

FIGURE 3.4. Deviated We11s and Earth Fracture System (not to scale) 


\subsection{ASSESSMENT OF ENV IRONMENTAL, HEALTH AND SAFETY IMPACTS}

The purpose of this section is to present an assessment of the environmental, health and safety impacts for normal operations during the development of a Devonian shale gas field. The potential impacts are examined for each of the steps covered in the previous section on recovery technology of natural gas from Devonian shale. The reference surface environment used for the assessment is described in Section 4.1. Potential environmental effects are discussed in Section 4.2 and health and safety concerns are evaluated in Section 4.3.

\subsection{DESCRIPTION OF DEVONIAN SHALE ENVIRONMENT}

The three primary regions of Devonian shale resource include the Michigan Basin, the Illinois Basin and the Appalachian Basin. All three of the basins are located in predominately hilly, rural, farming lands with some small towns nearby. (a) The majority of the soils are acidic with poor subsoil embankment stability, which causes them to have a high slip hazard. This makes these areas susceptible to small landslides, particularly in locations with steeper hills. Thus, erosion may be a significant concern in all these areas. Although the Devonian shale basins are predominantly rural areas, a number of roads are present. Most of the area has many small streams that extend into nearly every canyon. The size of these streams depends on the season. The streams are lowest in flow during the early fall and highest in flow during early spring.

The climate of these three basins is similar. Summers are warm and humid with heavy spring rains and occasional thunder showers. Winters are mild with light snowfall in the Appalachian basin areas of Kentucky, West Virginia and Ohio, becoming less mild northward into Pennsylvania and New York. Winters in the Michigan Basin are moderate to severe with moderate to heavy snowfalls. The Illinois Basin has winters similiar to the Michigan Basin.

(a) Wells are not normally located in urban areas. 
The hilly areas of the Devonian shale basins are characterized by deciduous forest vegetation. Tree species include white oak, maple, birch, beech and poplar. Most of the valleys are farmed or used for grazing. The fields and forest support populations of birds and mammals. Mammal species present include the white-tailed deer, opossum, racoon, skunk, muskrat, bobcat and numerous other small species. Characteristic reptiles are turtles, garter snakes, copperhead snakes and rattlesnakes. Various salamanders, toads and frogs are among the amphibians living in the area. Lizards are found only in sandy habitats within the region. Populations of passerine birds, various hawks and owls, and wild turkeys occupy the forest and field areas.

\subsection{ENVIRONMENTAL ASSESSMENT}

This section examines the potential impact of increased Devonian shale gas production on air quality, water quality and the ecology. Impacts for each of the steps in the development of a petroleum field (as described in Appendix A)will be examined sequentially in this section. Table 4.1 summarizes the potential environmental impacts from Devonian shale gas production. In most cases, as shown in previous DOE studies (DOE/ERD-0011, DOE/EDP-0049, and DOE/ERD-0022), the impacts are minor or temporary. A11 of these impacts are at least partially mitigated by existing Federal regulations.

Existing legislation and resultant regulations applicable to development of the Devonian shale resource are summarized in Table 4.2. This body of legislation provides the legal authority to control environmental, health and safety impacts from gas exploration and production operations in Devonian shale (as well as from most other industries) to acceptable levels. The regulatory framework to fully implement this legislation is still being developed. Methods to assure compliance with regulations are also not fully developed. The assessment presented in this document is based on current procedures and practices. Estimated impacts are based on site visits, discussions with people working in the field and information available in the literature. A number of states have regulations in place that control environmental impacts from these types of operations. These regulations are specific to each state and site and have not been considered in detail in this assessment. 
TABLE 4.1. Comparisons of Potential Environmental Impacts from Gas Field Development

\begin{tabular}{|c|c|c|c|c|c|c|c|c|c|c|}
\hline \multirow[b]{2}{*}{ Activity } & \multirow[b]{2}{*}{$\begin{array}{l}\text { Duration } \\
\text { of Activity }\end{array}$} & \multirow[b]{2}{*}{ Noise } & \multirow[b]{2}{*}{$\begin{array}{l}\text { Air } \\
\text { Pollution }\end{array}$} & \multicolumn{2}{|c|}{ Pollution of } & \multirow[b]{2}{*}{$\begin{array}{r}\text { Land } \\
\text { Use }\end{array}$} & \multirow[b]{2}{*}{ Flora } & \multirow[b]{2}{*}{ Fauna } & \multirow[b]{2}{*}{ Water Usage } & \multirow[b]{2}{*}{ Geological } \\
\hline & & & & $\begin{array}{c}\text { Surface } \\
\text { Water }\end{array}$ & $\begin{array}{l}\text { Ground } \\
\text { Water }\end{array}$ & & & & & \\
\hline Exploration & Very short & $\begin{array}{l}\text { Loud during } \\
\text { seismic blast }\end{array}$ & Very slight & $--\star$ & -- & - & Very slight & $\begin{array}{l}\text { Very slight } \\
\text { (noise) }\end{array}$ & -- & -- \\
\hline Drill Pad Siting & Short & Loud & Slight & Large & - & $1 / 2-2$ acres $/$ pad & $\begin{array}{l}\text { All vegetation } \\
\text { removed from } \\
\text { drill pad }\end{array}$ & Slight & -- & -- \\
\hline Drilling & Moderate & Very loud & Slight & Modera te & $\begin{array}{l}\text { None to } \\
\text { very slight }\end{array}$ & -- & -- & -- & Very slight & -- \\
\hline Stinulation & Very short & & $\begin{array}{l}\text { Moderate in } \\
\text { immediate area }\end{array}$ & Very slight & $\begin{array}{l}\text { None to } \\
\text { very slight }\end{array}$ & -- & -- & Very slight & $\begin{array}{l}\text { Slight. Water } \\
\text { may be trucked } \\
\text { in }\end{array}$ & Very slight \\
\hline Pipelines & Moderate & $\begin{array}{l}\text { Moderate during } \\
\text { construction }\end{array}$ & Slight & Moderate & -- & $\begin{array}{l}\text { Large areal } \\
\text { expansion }\end{array}$ & Moderate & Very slight & -- & - \\
\hline Roads & $\begin{array}{l}\text { Short to } \\
\text { moderate }\end{array}$ & $\begin{array}{l}\text { Moderate during } \\
\text { construction }\end{array}$ & Slight to moderate & Slight & -- & Sma 11 & Very slight & $\begin{array}{l}\text { Slight due to } \\
\text { noise, traffic }\end{array}$ & -- & -- \\
\hline Production & Very long & $\begin{array}{l}\text { Moderate for occa- } \\
\text { sional short periods }\end{array}$ & Slight & -- & -- & $\begin{array}{l}\text { Less than } \\
\text { dri11 pad }\end{array}$ & $\begin{array}{l}\text { Slight due } \\
\text { to traffic }\end{array}$ & $\begin{array}{l}\text { Slight due to } \\
\text { noise, traffic }\end{array}$ & -- & -- \\
\hline Restoration & Short & $\begin{array}{l}\text { Moderate during } \\
\text { restoration }\end{array}$ & Slight & -- & -- & $\begin{array}{l}\text { Return to } \\
\text { original use }\end{array}$ & -- & -- & Very slight & -- \\
\hline
\end{tabular}




\section{TABLE 4.2. Applicable Federal Environmental, Health and Safety Regulations (DOE/EDP 1979)}

Legislation
Clean Air Act
New Source Performance
Standards
Prevention of Significant
Deterioration
Nonattainment
Visibility
Federal Water Pollution
Control Act

Toxic Substances Control

Act
and Recovery Act

Safe Water and Drinking $\underline{\text { Act }}$

$\frac{\text { Occupational Safety and }}{\text { Health Act }}$

\section{Pollutant/Concern}

Fugitive emissions Particulates

$\mathrm{SO}_{\mathrm{x}}$

$\mathrm{NO}_{\mathrm{X}}$

Hydrocarbons

Polycyclic aromatics

Hydrogen sulfide

Ammonia

Accidental releases of noxious gases. $\left(\mathrm{CO}, \mathrm{H}_{2} \mathrm{~S}\right)$

Disposal of drilling wastes and produced waters

Subsidence

Injection flutds and products of production

Sludges from drilling mud cleanup and recovered brine

Injection fluids surface wastewaters

Explosives

Fires

Exposure to toxics
Current/Proposed Standards

Environmental assessment and environmental impact statement needed.

Ambient standards have been set for: $\mathrm{SO}_{2}, \mathrm{NO}_{x}$, particulates, $\mathrm{CO}$, Hyrdrocarbons, and oxydants.

NSPS have not yet been set.

A NPDES permit is required unless waste water is reinjected.

Subject to the Act if discharging into a navigable water.

If toxics are released or treated in effluent stream they will be regulated under Sec. 307.
Waste streams will require testing for hazardous waste.

If waste is classified as hazardous, the facilities will have to meet RCRA requirements.

Hazardous waste disposal must comply with air and water standards.

Potential impacts on siting.

Under injection permit will be be required--although the stringency is uncertain.

State regulations could restrict siting and injertion practices.

Public hearings on each permit application.

Maintain employee health and exposure records.

Revised toluene standard.

Facilities engaged in treatment, storage, or handling of hazardous waste will require permits.

New benzene standards. 


\subsubsection{Exploration}

There are three activities associated with exploration for gas contained within Devonian age shales that might result in environmental impacts: 1) seismic exploration, 2) construction of temporary roads, and 3) wildcat drilling. Wildcat drilling, from an environmental viewpoint, is the same as regular development drilling and, will be discussed in the development section.

Seismic exploration is not currently being done specifically for the Devonian shale. Some seismic exploration is being done in these general regions but is directed at deeper basins. The main impacts of seismic exploration result from a small amount of particulates released by the explosion and a short-term loud noise that could temporarily startle and frighten animals in the vicinity (Cotteneau 1978). Because of the abundance of local roads, very little off-road travel is needed to transport equipment. However, some off-road vehicular traffic may be needed for the transportation of exploration equipment. Off-road vehicular traffic damages every kind of ecosystems by damaging soil, crushing vegetation, and killing or disturbing wildlife. The local soils have poor subsoil embankment stability with a high slip hazard and are particularly vulnerable to off-road vehicular traffic, which could cause a large amount of erosion to occur. Alpine tundra areas of Appalachia and bogs (found in all three areas) are especially susceptible (Council of Environmental Quality 1979) to off-road vehicular traffic and should be avoided during exploration. Based on the large mileage of existing roads, the amount of land impacted by off-road vehicular traffic compared to the total land area of these three basins is small; therefore, the impact is minimal.

\subsubsection{Field Development}

The development of Devonian shale resembles the development of a conventional gas resource in that a large number of wells are usually drilled in a rather definitive area. However, in some cases only one or two wells are drilled in a region and therefore, will have smaller impacts. For purposes of this assessment, the development of the Devonian shale has been treated like that of more conventional gas resources to evaluate the maximum environmental effects that 
might be encountered. The "typical" field for this assessment occupies ten square miles and is developed on a 40-acre spacing (that is, there is a well in each 40-acre grid). Thus, this field has a total of 160 wells.

The activities associated with the development of a Devonian shale gas field are identical to those used in a conventional gas field. They include:

1. construction of raads

2. construction of pipelines

3. drilling of production wells

4. construction of distribution and treatment facilities

5. stimulation of production wells

6. seal-up wells, cleanup and abandonment of the field.

\subsubsection{Construction of Roads}

The construction of roads could result in a large area impact. A minimum of 40 miles of road would be required to develop the reference ten-square-mile well field. If no existing roads were available, the minimum cleared area would range from 145 acres (2.3\% of the total field area) for a $30-\mathrm{ft}$ roadbed to 100 acres $(1.5 \%)$ for a $20-\mathrm{ft}$ roadbed. In many cases, because the roads are being built in a hility region, the actual road miles would probabiy be about two times this minimum but would still only represent a disturbance of only 2 to $3 \%$ of the total well field area. Because most of the wells are expected to be located within a few feet of existing roads, it is expected that a maximum of 5-10 miles of new road construction would be required. Removal of flora and fauna will occur along all roadbeds. The amount of flora or fauna removed witl have a minimal effect on the total ecosystem because of the small amount of land involved.

Since there will be increased road traffic in the area, the probability for road kill of animals increases. However, the net road usage is low (a few trips per week), and the increased probability for road kills will be slight.

During the construction of the road, the principal pollutant will be air emissions of diesel engine exhaust and dust. The impact of diesel emissions on air quality is anticipated to be minimal except in the immediate vicinity of the road equipment because of good atmospheric dispersion characteristics in the area and the lack of sensitive environments in the immediate vicinity 
(Copenhaven et al. 1978, Clusen 1979). Dust may be a local problem at the construction site during dry weather and high wind conditions. This quantity of dust would be similar for any equivalent-sized road construction site. These regions already have very high total suspended particulate (TSP) levels. The small amount of road construction is anticipated to add very little to these TSP levels.

In addition to air pollutants, diesel engines create approximately 85$95 \mathrm{~dB}$ of noise at 50 feet (Adamson 1978). This level of noise will disturb neighboring fauna. It may cause them to flee from the immediate area and may also disturb breeding and brooding (Janssen 1978). However, road construction activities will last only a few days at one site so permanent impacts due to air and noise pollutants should not occur.

Erosion and runoff from the roadbed may result in some surface water pollution. However, since the amount of new road construction required is expected to be small, the potential for increased erosion impacts is quite small.

\subsubsection{Construction of Pipeline}

In addition to construction of roads for transportation of the necessary field equipment, development of a gas field requires construction of pipelines between wells and to the nearest commercial transmission pipeline. Within a 10-square mile gas field, the pipeline required will be approximately $40 \mathrm{mi}$. long. This is equal to the miminum road distance since the presence of hills will not significantly alter the pipeline length. Distance to the nearest commercial transmission pipeline is highly variable and may only be determined for a field-by-field case. If the pipelines are buried (though they need not be buried), a backhoe digs a trench about 10 inches wide by 30 inches deep that, after burial of the pipe, is recontoured and reseeded. Based on the 40 miles of pipeline, the total amount of land disturbed within the gas field would be approximately 30 acres $(0.5 \%$ of the total field area). Disturbance to flora and fauna would, therefore, be minimal. Noise and atmospheric emissions from the construction equipment will result in minor impacts because of their short duration and low levels.

\subsubsection{Drilling of Production Wells}

The major activity associated with development of the gas field is drilling the wells. The major impact from the drilling is clearing of the drill pad, 
which covers an area of about $1 / 2$ to $3 / 4$ acre. Included in this acreage is a lined mud pit for disposal of drilling muds and waste production water and a smaller flare pit where the produced gas is burned when testing the well. The mud pit is about $1250 \mathrm{ft}^{2}$ in area and the smaller flare pit occupies about $400 \mathrm{ft}^{2}$. Based on a 3/4-acre pad, the total area occupied by drill pads for the entire developed field will be about 120 acres (1.9\%).

All vegetation on the well pad sites is destroyed. If the wells are located in a cleared area or an old field, the animal habitat and plant cover destruction will be minimal. If it is necessary to site the well on a slope or hilltop, the topography of the area will be altered and part of the hillside will be leveled. Clearing a drill pad on a hillside can involve blasting and would have considerably more impact on the surrounding communities than merely locating the well on level ground at the bottom of one of the area's natural hollows. The disturbed vegetation and surface topography may lead to increased erosion. The additional siltation in the streams from erosion may have adverse effect on the aquatic life.

The construction equipment noise of about 85-95 dB at $50 \mathrm{ft}$ (Adamson 1978) will cause many animals to flee from the surrounding area and depending on the season of the year could interfere with breeding. This noise level is not expected to cause any permanent damage to the wildlife because the noise level is not excessive (Janssen 1978) and should last for a maximum of only about one month at each drilling site (Fields et al. 1973).

Air pollution resulting from construction of the drill pad will be caused by diesel engines and wind-blown dust. The diesel engines emit carbon monoxide $(\mathrm{CO})$, sulfur oxides $\left(\mathrm{SO}_{\mathrm{x}}\right)$, nitrogen oxides $\left(\mathrm{NO}_{\mathrm{x}}\right)$, hydrocarbons $(\mathrm{HC})$ and particulates. Dust will be produced from construction operations and from the cleared well pad. Dust and diesel emissions should have an impact only in the immediate vicinity of the construction site and should be well below air quality standards a short distance from the drill pad. During dry weather and highwind conditions, dust from the construction area would add to the local TSP levels although the addition will be very small.

During drilling, the major potential sources of pollution are the air emissions from the 1000- to 1500-hp diesel engines and ground water pollution 
from accidental spills from the drilling mud pit. The diesel engines will run continuously, 24 hours a day for somewhere between a few days and a month, depending on how deep the well is drilled. Primary emissions will be $\mathrm{CO}, \mathrm{SO}_{\mathrm{x}}, \mathrm{NO}_{\mathrm{x}}$, hydrocarbons and particulates. The quantities emitted by a diesel engine are given in Table 4.3. Normally, only one or two drilling rigs will be operational at a given time in a field. These emissions, averaged over the entire gas field, will be quite small and well within ambient air quality standards.

TABLE 4.3 Emissions from One 1100-hp Diesel Engine

Using "Diese1" Fuel (USEPA. 1972)

\begin{tabular}{|c|c|}
\hline Pollutant & $\begin{array}{l}\text { Quantity } \\
\text { (g/sec) }\end{array}$ \\
\hline $\mathrm{SO}_{\mathrm{x}}$ & 2.08 \\
\hline$H C^{\wedge}$ & 1.63 \\
\hline $\mathrm{NO}_{x}$ & 2.84 \\
\hline $\mathrm{CO}^{\wedge}$ & 2.50 \\
\hline Particulate & 0.80 \\
\hline Aldehydes & 0.13 \\
\hline
\end{tabular}

The noise generated by the diesel engines will be approximately $90 \mathrm{~dB}$ at 50 feet. Wild animals who are sensitive to high noise levels will flee from this area; however, most of the local fauna may be domesticated or semidomesticated animals who should be able to tolerate these noise levels.

It is expected that homes will be scattered around the area near the drill site. Some may be close enough to the drilling site to be disturbed by the noise. This disturbance is based on the EPA prescribed maximum safe levels of $45 \mathrm{~dB}$ during the night from $10 \mathrm{p} . \mathrm{m}$. to 7 a.m. (see Fig. 4-1, p. 4-15). This maximum noise level could be exceeded within a 2-mile radius if hills or other topographical features do not block or otherwise attenuate the noise levels (Adamson 1978). However since drilling lasts one month or less, this should not be a major obstacle.

If mud is used during drilling, a small mud pit of $1250 \mathrm{ft}^{2}$ will be dug to hold the mud. The mud pit is normally lined to prevent groundwater contamination. 
In most cases, air or gas is used in drilling instead of mud because it speeds up the drilling rate. The use of air or gas as an alternative to mud would eliminate any environmental impacts associated with the mud pit since this facility would not be required in an operation using air or gas. Gas or air drilling may, however, result in localized increases in particulates. If drilling mud is used, constituents of the drill mud water are nomally non-toxic and have been deemed so by the EPA in conjunction with the Resource Conservation and Recovery Act of 1976 (RCRA) (PN-94-580). The only toxic element that could be present in mud or naturally contaminated waste water is barium. The concentration of the element is expected to be less than the $10-\mathrm{mg} / \mathrm{e}$ level set by EPA as the concentration that is potentially toxic to public health (National Interim Drinking Water Regulations 1976). Under normal conditions, drilling mud fluid will be isolated from public exposure pathways by high dikes. These dikes will also protect the surface waters in the area from contact with the mud. The pits are fenced to prevent ground animals from drinking the fluids. Where migratory bird flyways may overlap the drilling areas, state and federal regulations require that the mud pits be covered to prevent access to the waste fluids.

\subsubsection{Construction of Distribution and Treatment Facilities}

At each well site in the gas field, distribution and gas treatment facilities are constructed to collect the gas, remove liquid gas elements and pump the gas into the local pipeline. Construction of these facilities will be on the 3/4-acre pad previously cleared for the drill site and requires only hauling in and hooking up the necessary machinery. Therefore, impacts on air quality, wildlife or waterways should be minimal during this step.

For the total field, a small compressor station must also be constructed. This construction will require the clearing and leveling of an area of approximately 1/4 acre. The next step will be hauling in and hooking up the compressor. This activity will take only a few days and should have only a small impact.

\subsubsection{Stimulation of Production Wells}

To get reasonable flow rates, the wells must be stimulated using some form of advanced hydraulic fracturing. From an environmental viewpoint, all of the advanced hydraulic fracturing techniques discussed in Section 3 are 
equivalent. Separate assessments for each method were not required. The principal potential pollution sources during stimulation are exhaust emissions from diesel engines during the fracturing job and minor spills of the chemicals used in the fracturing fluid. During the fracturing job, several large diesel engines will be used to pump the fluid under high pressure into the well. For example, for a hydraulic fracturing job of 20,000 to 50,000 gallons, there will be one pump truck and one blender or mixer truck each with two large diesel engines. If a foam fracturing method is used, there will be one additional nitrogen pump truck. These large diesel engines will result in local high concentrations of air pollutants and high levels of noise. The air pollution levels expected during the 1/2-to-2 hour operation are given in Table 4.4 .

TABLE 4.4 Emissions from a Typical Stimulation Job Using Three 1100-hp Diesel Engines Burning "Diesel" Fuel (USEPA 1972)

\begin{tabular}{lcccc} 
Pollutant & $\begin{array}{c}\text { Release Rate } \\
(\mathrm{g} / \mathrm{sec})\end{array}$ & $\begin{array}{c}\text { Release During } \\
\text { Typal Sized Job } \\
(\mathrm{kg} / \mathrm{hr})\end{array}$ & $\begin{array}{c}\text { Total Release } \\
\text { for a two-Hour } \\
\text { Job }(\mathrm{kg})\end{array}$ \\
\cline { 1 - 1 } $\mathrm{SO}_{\mathrm{X}}$ & 21.23 & 23 & 46 \\
$\mathrm{HC}$ & 16.6 & 18 & 36 \\
$\mathrm{NO} \mathrm{X}_{\mathrm{X}}$ & 28.93 & 31 & 62 \\
CO & 25.46 & 28 & 56 \\
Particulate & 8.2 & 9 & 18 \\
Aldehyde & 1.32 & 1.2 & & 2.4
\end{tabular}

Local air quality standards will probably be exceeded only within a short distance of the well site. However, when averaged over the entire field, the standards should not be exceeded.

Noise levels will also be very high, about $100 \mathrm{~dB}$ at the center of the pad or $58 \mathrm{~dB}$ at $400 \mathrm{ft}$ from the engine (Adamson 1978). This latter level of noise is about the level of normal conversation and may cause dispersal of fauna.

Fracturing jobs usually last one-half to two hours and, therefore, the impacts over the long term will probably not be measurable. The constituents of fracturing fluid are non-toxic, so provided spills are cleaned up, minimal impact from chemical spills will result. 
Another potential source of environmental impact during well stimulation is contamination of freshwater aquifers with fracturing fluid components. Standard oilfield practices to prevent this seem to be effective. It is anticipated that groundwater contamination will only occur if the cementing of the casing has not been properly done. The possibility of stimulating a well with an inadequate cement job is believed to be low because a cement bond $\log$ is run previously to insure a good bond. Some uncertainties surround this issue because the overall effectiveness of the current control techniques is not know.

Concern has been expressed that hydraulic fracturing operations might lead to increased seismic activity. Fracturing operations should not result in seismic events in these basins because:

- The volume used in a fracturing job is from one-hundredth to one-tenthousandth of the amount which have triggered seismic events.

- None of the three basins is seismically active.

- Past fracturing jobs have not resulted in seismic or other subsurface activity (Pakisen et a1. 1969, and Tonnessen. 1977.)

\subsubsection{Production}

During the production phase, there is a decrease in the noise levels, the human activity, and the air pollution. The only noise that may occur from the site is when the gas is compressed before entering the pipeline (Adamson 1978). Compressors can be extremely noisy but may be housed in a building to decrease the noise to acceptable levels where noise might be a problem. There may also be intermittent high-noise levels during routine maintenance checks. This should be minimal compared to drilling or fracturing. A small number of road kills of animals might result during the transportation of maintenance crews. However, this incremental road traffic is minimal causing this impact to be small.

\subsubsection{Abandonment}

Site restoration is an important last step in the life of a gas field. Certain procedures such as plugging and marking of a well are covered by the states permitting processes. Other procedures can be stated within the surface owner's lease. 
In general, a work-over rig will be brought in to remove the well casing. Then, a cement slurry will be pumped down the hole, and it will be plugged from the bottom to the top with cement. Both of these procedures will require the intermittent use of diesel motors with their emissions and noise. However, both procedures are of very short duration and thus, the overall environmental impacts are minimal.

Al1 of the surface facilities will be dismantled and removed. This will require personnel, lifting equipment and large trucks. These tasks will be of very short duration with minimal impacts.

The final procedure is to either recontour and reseed all disturbed land (roads and drill pads) back to their original conditions or to leave the land as specified in the lease. If the landowner desires, the site, including roads and drill pad, may be left for his use after being cleaned and decontaminated. Recontouring and reseeding activities will require the use of equipment with diesel motors similar to the construction activities and should likewise result in no measurable air quality impact. Seeding should reduce erosion possibilities and the local fauna population would return to normal.

\subsection{HEALTH AND SAFETY ASSESSMENT}

This section will examine the human health and safety impacts that could potentially result from development of a Devonian shale gas field. These impacts were discerned by site visitation, discussions with workers and by a review of available literature. The primary areas of interest are the health and safety effects of noise, air pollution and accidents.

\subsubsection{Noise}

Ambient noise levels will be increased in the vicinity of the well site during the development period, especially during the drilling and fracturing phases of the operation. Sources of potentially significant increases in noise levels include: operation of service vehicles and construction equipment, the operation of generators and diesel motors during drilling and stimulation and pumping operations, and the noise resulting from the general increase in the level of activity at the site. Typical noise levels at 50 feet for specific components of the operation are (Adamson 1978, pp. 40-41): 


$\begin{array}{ll}\text { scraper } & 88-95 \text { decibels (dBa) } \\ \text { grader } & 77-87 \mathrm{dBa} \\ \text { truck } & 66-91 \mathrm{dBa} \\ \text { dri1ling rig } & 290 \mathrm{dBa} \\ \text { fracturing } & 90-100 \mathrm{dBa} .\end{array}$

Figure 4.1 (Turk, Turk and Wittes 1972) shows the decibel levels and verbal loudness description of various sounds. In general, noise levels of about 80 decibels or higher can produce permanent hearing loss; however, the effect is faster for louder noises. For example, exposure to a 95-decibel noise in an occupation will depress a person's hearing ability by 15 decibels in 10 years. To prevent this hearing loss, the onsite workers need hearing protection according to OSHA (Occupational Safety and Health Administration) requirements. Table 4.5 shows the OSHA standards for noise exposure in the work place. Although hearing protection is usually provided, it is often not used. Table 4.6 summarizes the Environmental Protection Agency (EPA) standards for non-ambient noise levels (PL 92-574).

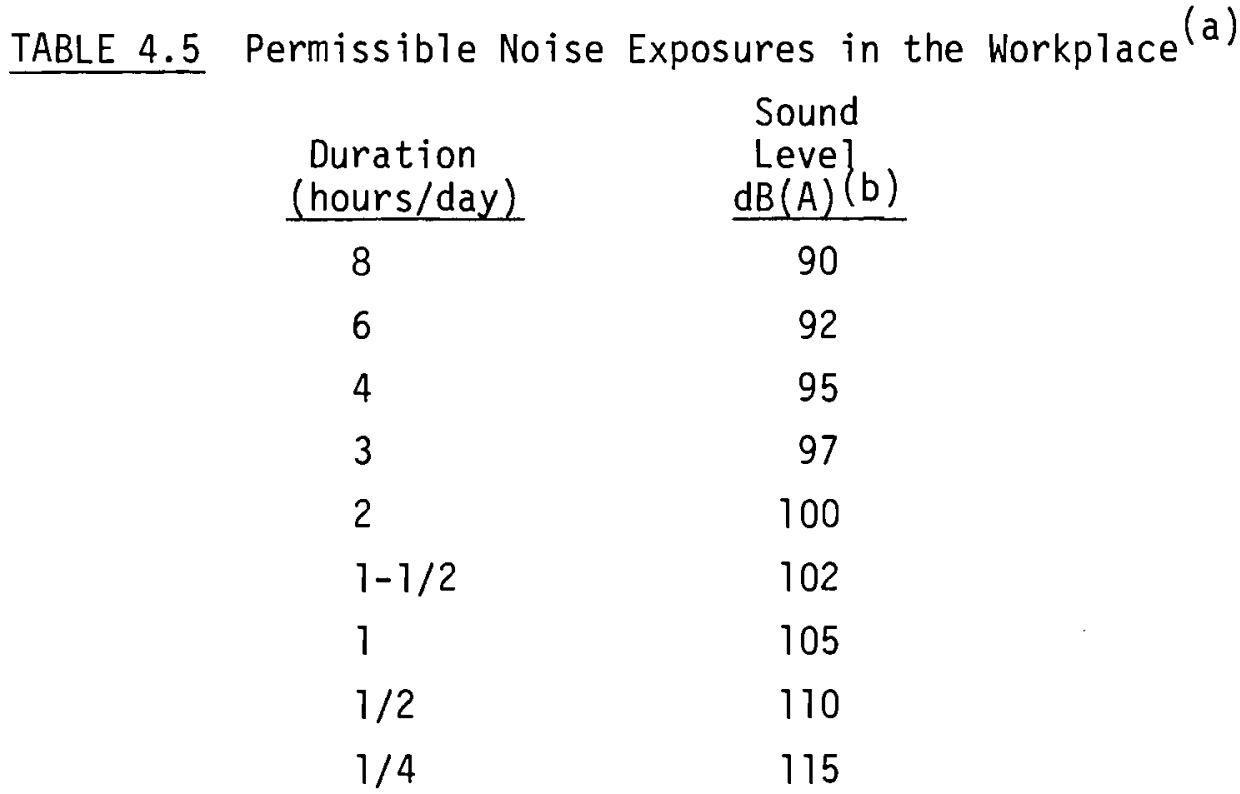

(a) OSHA Standards for Noise Exposure in the Workplace, Bureau of National Affairs, Washington, DC.

(b) $d B(A)=$ decibels over ambient. 


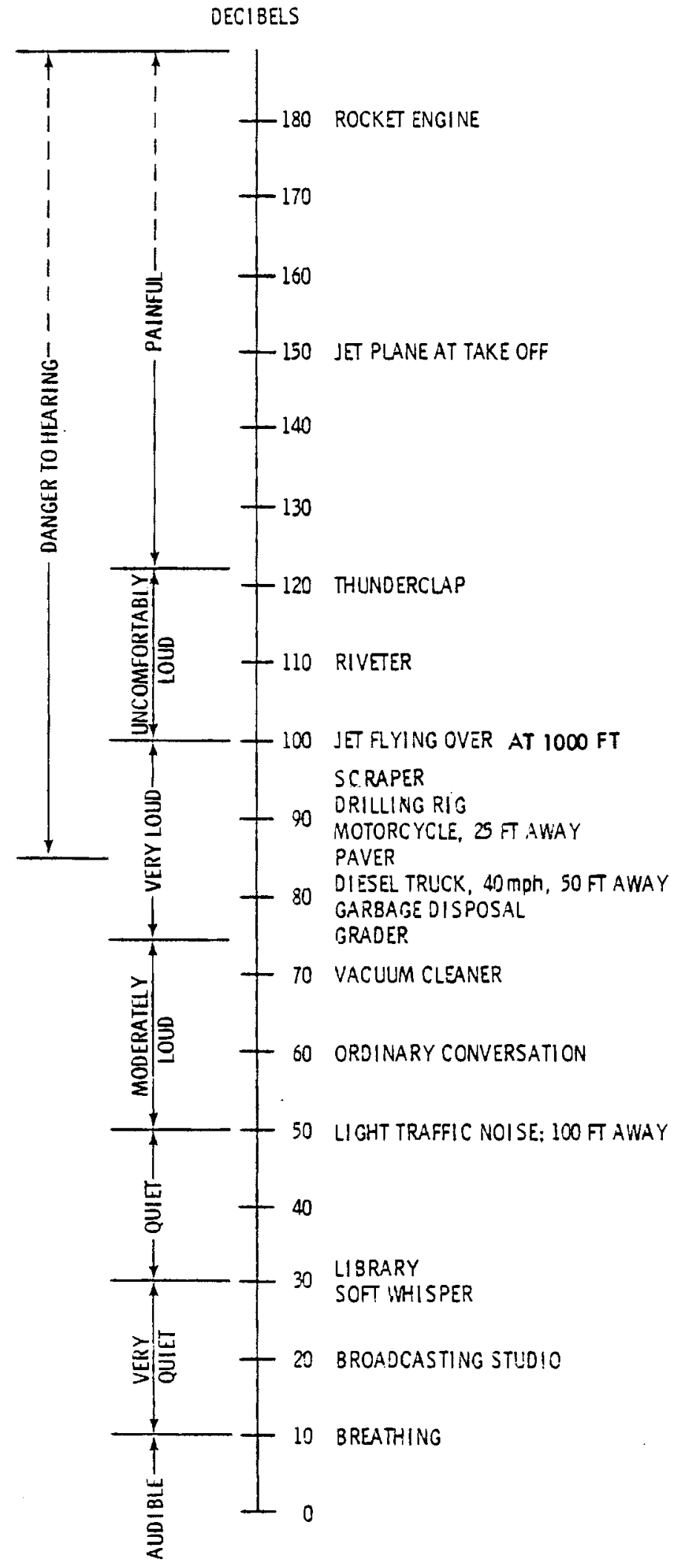

FIGURE 4.1. Decibel Levels and Verbal Loudness Descriptions of Various Sounds 
TABLE 4.6 Summary of Noise Levels Identified as Requisite to Protect Public Health and Welfare with an Adequate Margin of Safety(a)

$\begin{array}{ll}\frac{\text { Effect }}{\text { Hearing loss }} & \frac{\text { Level }}{\text { Leg }}(\mathrm{b})(24) \leq 55 \mathrm{~dB} \\ \begin{array}{l}\text { Outdoor activity } \\ \text { interference and } \\ \text { annoyance }\end{array} & L_{\mathrm{dn}}(\mathrm{c}) \leq 55 \mathrm{~dB}\end{array}$

Leg $(24) \leq 55 d B$

Indoor activity
interference and
annoyance

$\mathrm{L}_{\mathrm{dn}} \leq 45 \mathrm{~dB}$

Leg $\leq 45 \mathrm{~dB}$
Area

A11 areas.

Outdoors in residential areas and farms and other outdoor areas where people spend widely varying amounts of time and other places where quiet is a basis for use.

Outdoor areas where people spend limited amounts of time, such as schoolyards, playgrounds, etc.

Indoor residential areas

Other indoor areas with human activities such as schools, etc.

(a) EPA, Environmental Protection Agency Standards for Non-Ambient Levels, PL 92-574.

(b) Leg (24) = Sound energy averaged over 24-hour period.

(c) $L_{d n}=$ Leg with a $10-d B$ nighttime weighting.

\subsubsection{Air Pollution}

During much of the well field development, diesel trucks and engines will be operating, releasing into the air $\mathrm{CO}, \mathrm{SO}_{x}, \mathrm{NO}_{x}$, hydrocarbons and particulates. The concentrations of these constituents at any time depends on the number of engines operating and atmospheric conditions. The highest concentration of these air pollutants is most likely to occur during a fracturing job. At this time, diesel engines will be operating at full capacity. The amounts of each of the air pollutants produced during full operation were presented in Table 4.4.

CO produced from these operations is expected to reach 15-50 ppm near the source under calm wind conditions. These levels will not exceed the threshold limit value for workroom environments but could cause somatic effects in workers. Myers et al. (1970) estimates that $50 \mathrm{ppm}$ would be the level at' which one might expect some reduced mental acuity and headaches over a 10-hour 
period (see Figure 4.2). Since noise is believed to lower susceptibility levels, one would also suspect that co combined with elevated noise levels may have a synergistic effect, thereby intensifying the potential effects on mental acuity.

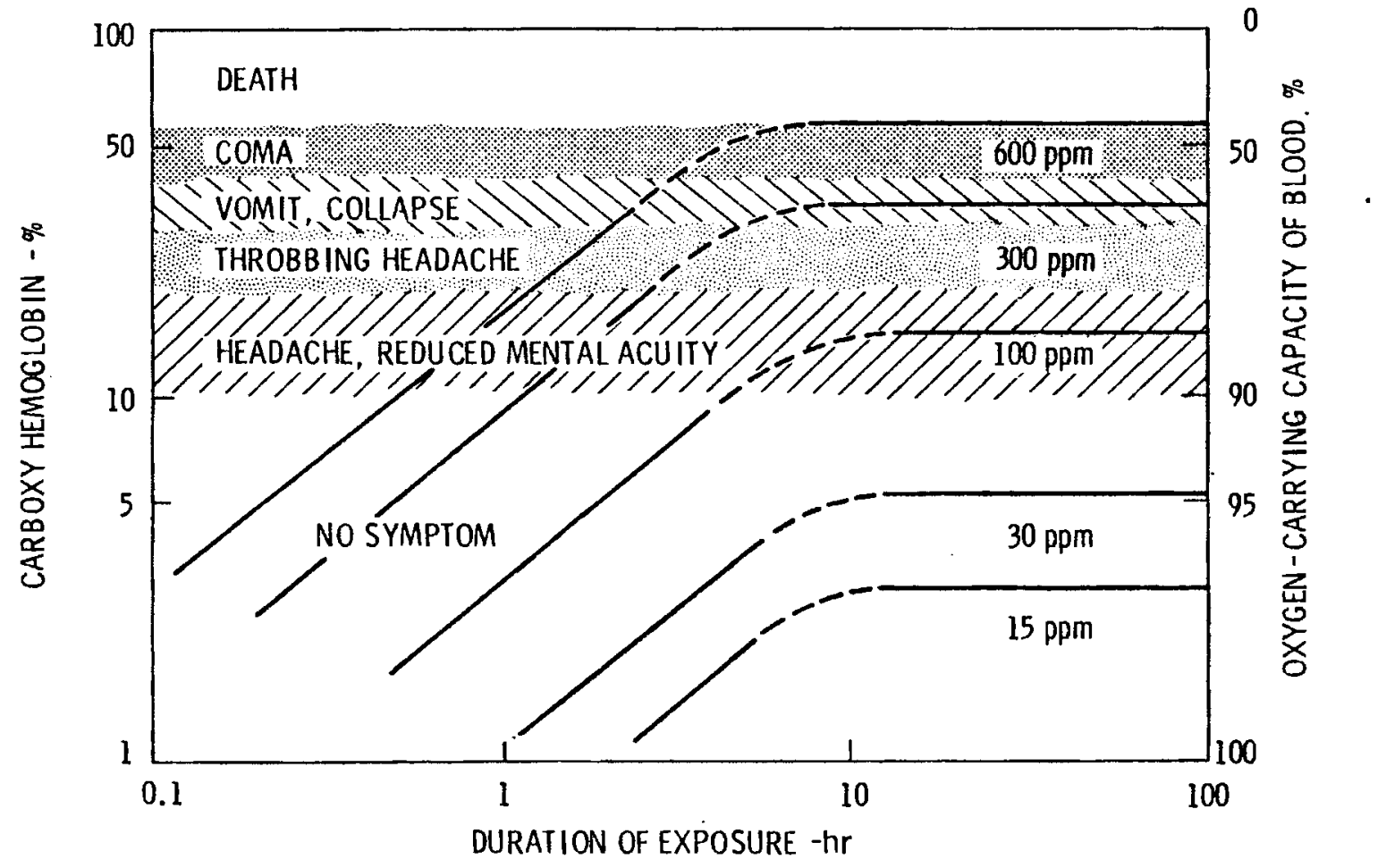

FIGURE 4.2 Relationship Between CO Exposure (Hours and Concentration) and Health Effects.

Other effects of slightly elevated carbon monoxide concentrations include cardiac function effects ( $230 \mathrm{ppm} \mathrm{CO})$ and work performance impairment ( $120 \mathrm{ppm}$ ). However, repeated exposure to low concentrations of the gas, up to $100 \mathrm{ppm}$, is generally believed to cause no signs of poison or permanent damage (Sax 1957).

Based on the calculated concentrations of the diesel exhaust constituents, these constituents such as sulfur dioxide $\left(\mathrm{SO}_{2}\right)$, photochemical oxidants, nitrogen dioxide, and particulates are not expected to exceed the "alert levels" 
as specified in the Clean Air Act (PL 91-604). More research is needed to determine the health effects of diesel exhaust since diesel particulates are bonded to organic compounds some of which have been shown to be at least mutagenic and may be carcinogenic (Environmental Reporter 1979).

Particulates due to traffic, construction of roads and drill pads, and wind scouring of exposed surfaces will present some air pollution problem. Each new mile of road and acre of cleared drill pad will add to the particulate grain loading of the local area. Such effects, however, will be extremely localized, especially for dusts greater than 5 micrometers $(\mu)$ in diameter. Based on this size particle, only unstable atmospheric/high wind conditions will permit the carrying of dust particles more than one kilometer. The only potential health hazard would be the enhanced spreading of airborne fungi attached to dust particles which may be subsequently inhaled by susceptible. individuals. Such cases are rare, the most notable being San Joaquin Valley Fever (Coccidiomycocis) in southern California (Berenson 1975).

Another source of airborne pollutants is windborne fracturing fluid chemicals during the fracturing process. Proper handling procedures will eliminate this source of pollutant.

\subsubsection{Accidents}

Accidents that can result in injury to workers happen in any industry. Gas well drilling is a relativeily accident free environment (National Safety Council 1977). Very few major accidents are expected al though numerous minor injury accidents will occur because of the proximity of heavy equipment.

Operations to discover and extract gas from Devonian shale resources are expected to be very similar to operations in other petroleum resources. General petroleum industry accident data can therefore be used to estimate occupational safety impacts from exploitation of the Devonian shale resource. Data on occupational injuries and fatalities for the petroleum industry are summarized by job category in Tables 4.7 and 4.8. Using this data gives average injury rates of 0.04 /worker for exploration and production operations, 0.27 /worker for drilling and 0.05/worker for pipeline construction and operation. The average industry fatality rate obtained from this data is $1.3 \times 10^{-4} /$ worker. Use of these fatality and injury rates 
TABLE 4.7. Summary of Fatal Injuries in the Petroleum Industry, 1974 to 1979

\begin{tabular}{|c|c|c|c|c|c|c|}
\hline \multirow[b]{2}{*}{ Job Category } & \multicolumn{6}{|c|}{ Number of Fatal Injuries per Year } \\
\hline & 1974 & 1975 & 1976 & 1977 & 1978 & 1979 \\
\hline $\begin{array}{l}\text { Exploration and } \\
\text { Production }\end{array}$ & 19 & 7 & 7 & 23 & 19 & 10 \\
\hline Gas Processing & 0 & 0 & 0 & 1 & 0 & 1 \\
\hline Gas Pipeline & 3 & 3 & 0 & 0 & 1 & 1 \\
\hline Drilling & 1 & 2 & 0 & 0 & 0 & 0 \\
\hline Total Employees & -- & 424,904 & 417,713 & 425,629 & 435,524 & 447,040 \\
\hline $\begin{array}{l}\text { Number of Workers per } \\
1 \text { Fatality }\end{array}$ & 5,806 & 8,498 & 10,188 & 5,995 & 5,807 & 8,597 \\
\hline $\begin{array}{l}\text { Total Industrial } \\
\text { Fatalities }\end{array}$ & -- & 50 & 41 & 71 & 75 & 52 \\
\hline
\end{tabular}

TABLE 4.8. Summary of Occupational Injuries in the Petroleum Industry, 1975 to 1979

Job Category

Exploration and Production

Total Number of Employees

Total Number of Injuries

Gas Processing

Total Number of Employees

Total Number of Injuries

Drilling

Total Number of Employees

Total Number of Injuries

Gas Pipeline

Total Number of Employees

Total Number of Injuries \begin{tabular}{lll} 
Number of Occupational & Injuries/Year \\
\hline $1975 \quad 1976 \quad 1977 \quad 1978 \quad 1979$
\end{tabular}

Avg.

$\begin{array}{rlllll}54,598 & 60,866 & 68,537 & 72,749 & 79,543 & 67,240\end{array}$

$\begin{array}{llllll}2,466 & 2,591 & 2,642 & 2,758 & 2,777 & 2,650\end{array}$

$5,927 \quad 7,084$

6,083

7,220

8,082

6,880

299

288

306

318

347

310

1,918

2,486

2,794

2,947

2,534

2,535

515

608

904

809

541

675

16,736

16,365

16,697

18,551

18,198

17,300

921

835

921

859

965

900 
should provide a conservative estimate of the fatalities and injuries that may be experienced in Devonian shale gas production because the data includes offshore and deep drilling operations that will be inherently more hazardous than operations in Devonian shale.

An estimate of occupational injuries and fatalities has been developed for the year 2000, when it is assumed that about 1 TCF of gas per year will be extracted. It has been estimated that about 126,000 active wells would be required to produce this gas, and that about 330 drilling rigs will be in operation in this resource (National Petroleum Council, 1980). About $2000 \mathrm{miles}$ of pipeline with 40 major compressor stations would be required to collect and distribute the gas. Each ten wells are assumed to have a minor compressor station. Half the wells receive regular routine maintenance and testing, while the other half are not on a routine maintenance schedule.

Using this industry scenario and assuming current practices are followed, the number of workers involved in various operations in the Devonian shale resource can be estimated. These estimates are summarized in Table 4.9 and discussed in more detail below. The table also presents fatality and injury estimates obtained using the fatality and injury rates developed above.

Drilling rigs typically require a 3-man crew for each shift. Assuming a 3-shift/day operation and 290 operating days per year, 2970 workers would be employed in drilling operations in the reference year.

TABLE 4.9. Summary of Occupational Injuries and Fatalities in Devonian Shale Gas Production in the Year 2000

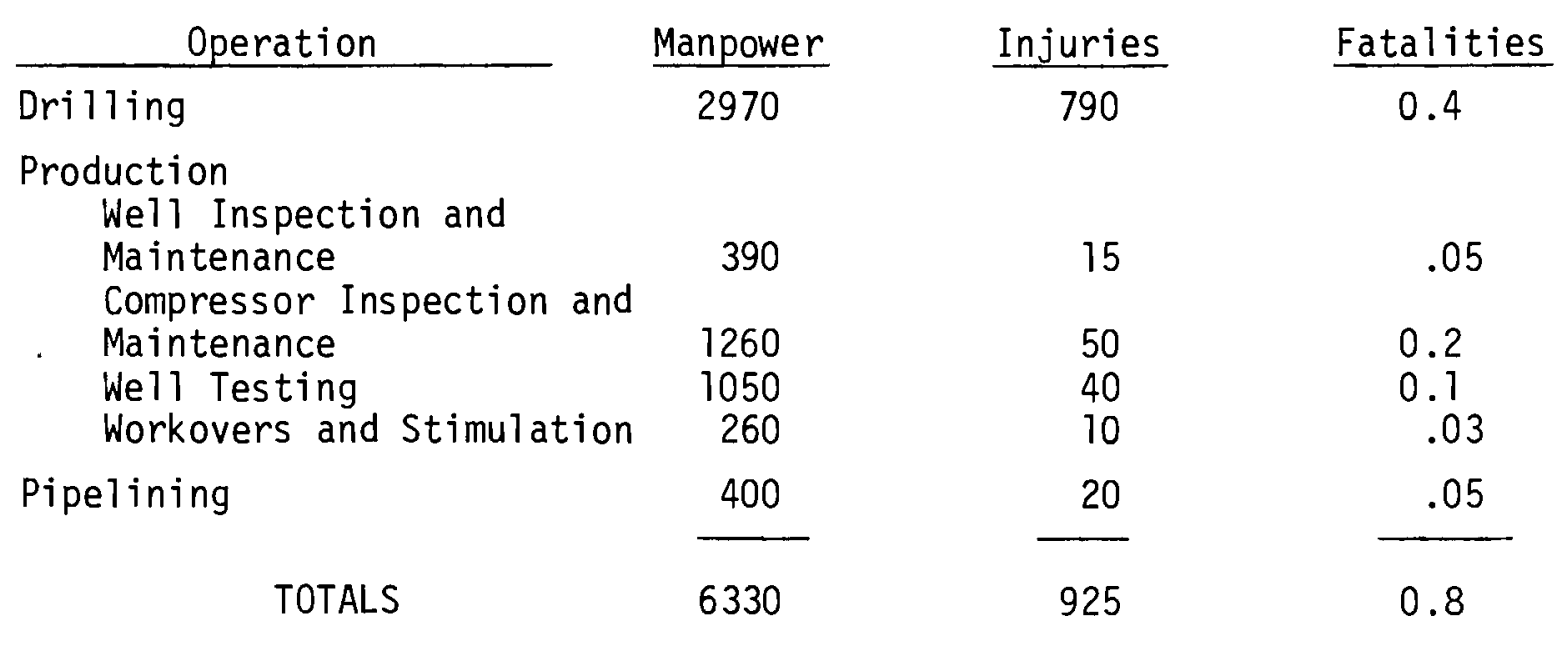


Wells are typically inspected about once every four weeks. In a typical field, an average worker can inspect about eight wells per day. Assuming 240 man days/man year, each worker could perform all the periodic inspection operations for about 160 wells. If 63,000 wells are being routinely inspected in the reference year, 390 people would be employed in inspection operations.

For compressor inspection and maintenance, each employee is assumed to be responsible for 10 minor compressor stations. This results in 1260 people employed in these operations, since each 10 wells is assumed to require a minor compressor station.

Each well in the reference year is assumed to require testing once a year. A crew of two men would typically take two days to perform this operation. This results in an estimated 1050 people employed in well testing in the reference year.

About $10 \%$ of the active wells are assumed to require workover and restimulation in the reference year. These operations typically take one day using a five-man crew. Again using 240 man-days/man year, about 260 people would be employed in these operations in the reference year.

A major compressor station is assumed to be required for each 50 miles of gas pipeline. A crew of 10 workers is estimated to be required at each compressor station. One airplane and pilot would also be required for routine pipeline inspection. This yields an estimate of 400 people engaged in pipeline operations associated with the Devonian shale resource in the reference year.

Occupational injuries and fatalities in Devonian shale are expected to be below the numbers obtained here using industry-wide estimates. This level of occupational injuries and fatalities has not been a barrier to recovery of petroleum from other resources. It is not expected to be a factor in commercialization of production of gas from Devonian shale. 


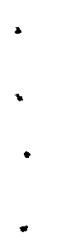




\subsection{CONCLUSIONS ANID RECOMMENDATIONS}

No significant environmental barriers to the development of the Devonian shale natural gas resource have been identified. While there are a number of important environmental regulations which are applicable to this resource, at this time they do not appear to be barriers to development of the resource. The most important environmental impacts identified were from potential health and safety impacts occurring during drilling and fracturing operations. Health impacts could result from the diesel emissions that are released from the diesel engines combined with high noise levels. The importance of these effects is not known at this time. However, these concerns are not unique to gas recovery operations in Devonian shale, nor to the petroleum industry as a whole. It is possible that future health effects research could indicate the need for additional controls in this area. It appears that such controls could be implemented without any major effects on the viability of Devonian shales as a gas resource. The safety impacts from operations in the Devonian shale resource are low and result from the general dangers associated with the utilization of heavy construction equipment.

Environmental impacts can also result from road construction, construction of the well pad, pipeline construction, and drilling of the well. However, it appears that most of these environmental effects would be small and affect only localized areas for relatively short periods of time. There are limitations in current abilities to predict and assess some of the health and safety effects. It is therefore recommended that further work be done to improve knowledge in the areas of health and safety impacts of chronic exposure to high levels of diesel emissions, including synergistic effects when combined with high levels of noise.

Pollution of ground water during well stimulation has been identified as another area with potential to produce significant environmental effects. Procedures in place to prevent ground water contamination appear to be effective. There are no procedures currently in use to monitor for groundwater pollution directly. Procedures currently available to perform groundwater monitoring, such as drilling test wells, are economically prohibitive and 
their use could result in a net increase in negative environmental effects. Because of the uncertainties surrounding this issue, it is recommended that a research program be developed to determine the effectiveness of current techniques used to prevent ground water contamination. This program could form the basis for developing new controls, if they are needed.

The principal barriers to utilization of this resource are technical, economic and legal in nature. Technical barriers are expected to be overcome by current research and development projects planned and underway. Although some success has been achieved in locating and producing Devonian shale gas with current technologies, improvements are needed. Current government pricing policies are expected to overcome the economic barrier. The legal barrier of finding mineral rights ownership information within the Appalachian region appears to only cause slight delays in resource development and should decrease in importance with time.

Problems of pipeline availability are expected to be overcome by the encouragement of local usage such as has occurred at Houghton College in New York state. A program that will encourage more local usage by small industrial parks, colleges and other small users is recommended. Such usage will reduce the main pipeline load and will make many areas energy self-sufficient. $A$ research program is needed to discover the most effective way to accomplish this objective. This program could form the basis for increased utilization of this resource.

This resource accounts for almost $50 \%$ of our total unconventional gas resources. However, because of the relatively low productivity of most Devonian shale natural gas wells, this resource may never supply more than $10 \%$ of our annual natural gas consumption. However, this is still a significant quantity of natural gas. Devonian shale should be capable of yielding from one to two trillion standard cubic feet per year of natural gas by the year 2000 . 
APPENDIX A

PETROLEUM FIELD TECHNOLOGY 


\section{APPENDIX A \\ PETROLEUM FIELD TECHNOLOGY $(a)$}

During its first half century, the American 0il Industry found petroleum resources by using the skills of experienced oilmen who spent their lives in the oil field. It was not until the second decade of the 20th century that the petroleum sciences, including geophysics, geology, and petroleum engineering, became important in finding and developing petroleum fields. The technologies for the location and exploitation of petroleum resources have continued to evolve since then.

Petroleum exploration, discovery, development, and production are scientifically and technically based functions which utilize information from the physical sciences, the earth sciences, and petroleum engineering. The exploration and initial drilling efforts combine the expertise of the geophysicist, geologist, and engineer. The development work is principally the job of the engineer, with assistance from the geologist and a very slight contribution from the geophysicist. Production and resource processing are tasks directed by the engineer. Thus, full cooperation among these three disciplines is required to effectively develop petroleum resources.

Presented in this section, in a generic sense, are the numerous stages in the exploration and exploitation of a petroleum (gas) field. The general steps in the finding and development of a petroleum resource are listed in Table A.1. Not all the steps may be required for each well within a given field.

\section{A.1 EXPLORATION}

Petroleum exploration covers all of the techniques, including the drilling of wildcat wells, which may be used in locating geologic traps that could contain petroleum accumulations. It utilizes the tools of geology and geophysics. Geologists examine the rocks themselves or work with rock properties that are measured by devices in close proximity to the rocks. Geophysicistsobtain additional information by measuring physical characteristics of the earth from a distance which is only indirectly related to geology.

(a) Petroleum is used here as a generic term for any oil or gas field. Until a wildcat well is drilled and tested, it is not known whether it contains oil, gas, or both. Most "gas" wells produce some condensate (oil). 
TABLE A. 1. Stages in the Recovery of Petroleum for Reservoirs

1. EXPLORATION

- Regional Surveys

- Detailed Surveys

- Wildcat Drilling

2. FIELD DEVELOPMENT

- Reservoir Definition

- Planning Well Space and Location

- Installation of Treating Facilities

- Collection and Distribution Facilities

3. PRODUCTION

- Surface Facilities Maintenance

- Welr Maintenance

- Stimulation

4. ABANDONMENT

- Plug Wells (cement to surface) and Mark

- Remove Surface Facilities

- Recontour and Reseed Well Sites and Lease Roads.

\section{A.1.1 Regional Surveys}

Regional exploration surveys employ environmentally passive techniques. The geologist creates maps of the earth's gross surface features using aerial photos and various earth satellite imagery which may show important underground structures. The geophysicist uses airborne instruments to measure and map abnormalities in both the earth's magnetic and gravitational fields. Both of these kinds of maps are used to delineate features that may require further examination.

A chemical survey technique, gas chromatography, can also be used to locate petroleum reservoirs by locating and identifying hydrocarbons which seep into the atmosphere. Both gas and oil deposits have been successfulty located via hydrocarbon seeps.

\section{A.1.2 Detailed Surveys}

When regional surveys indicate that promising subsurface features are present, more detailed surveys are conducted. The most important technique is three-dimensional seismic mapping. Another technique is detailed geological surface mapping, which includes precisely locating rock outcrops, describing the many characteristics of the different strata, and mapping their geometry and areal distribution. 
The seismic technique is by far the most sophisticated, complex, and useful technique in petroleum exploration. Seismic data are collected by sending sound waves into the ground. These sound waves are, in turn, reflected and refracted by the subsurface geologic strata and are recorded on the surface by sensitive receivers (geophones).

The most common technique used to generate sound waves has been with the use of dynamite or some other type of explosive. However, newer and less environmentally destructive methods are available that have the advantages over dynamite of eliminating the shot hole and generating a purer frequency.

The principal non-dynamite energy sources are Vibroseis and Dinoseis? The Vibroseis system utilizes a heavy weight which is coupled to the ground and then vibrated through a controlled frequency range. The Dinoseis system also employs a heavy weight held in contact with the ground. However, with Dinoseis, energy comes from the explosion of gases in a chamber attached to the weight.

Seismic data are interpreted through the use of very sophisticated computer programs. Following sophisticated corrections and filtering operations on the raw data a seismic map is generated. These seismic maps show the depth and geologic nature of each type of subsurface bed. In fact, they can even distinguish gas sands from those not containing gas. More important, they can locate stratigraphic and paleogeomorphic traps or unconformities that may contain petroleum.

\section{A.1.3 Wildcat Drilling}

The previous exploration techniques can only indicate structures which could be potential petroleum traps. The actual location of a petroleum deposit and determination as to whether it contains commercial quantities of $0 i 1$ or gas require that a well be drilled and tested. Any well which is drilled into a locally new zone is considered to be a wildcat well.

Once a site for the wildcat well has been selected, permits to build a temporary road and approval of the complete drilling plan must be obtained. Since wildcats enter new zones, the danger of blowouts is greater than the drilling of a developmental well. The actual drilling operation is similar to drilling any well and will be discussed in the following section. Figure A.1 shows the main features of a drilling rig. Figure A.2 illustrates the main features of a typical casing string.

QRegistered trademark of Continental $0 i 1$ Co.

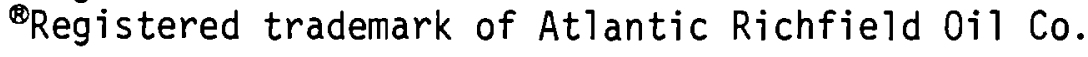




\section{A.2 FIELD DEVELOPMENT}

The initial wells drilled into a zone previously identified by geological and/or geophysical exploration are termed wildcats. These wells are used to define the areal extent of the reservoir, the number of productive zones, their continuity, and the production capabilities. Once these factors have been determined, the field will be developed on a regular surface spacing which is normally dictated by state and/or federal regulations. Common well spacings for gas wells are 40 acres/well, 80 acres/we 11, 160 acres/well, 320 acres/well, and 640 acres/. we11. The number of wells drilled into a field during development is usually dependent on the depth of the producing zone, i.e., the deeper the zone, the fewer the wells that will be drilled. It is assumed that a lease to the mineral rights has been previously obtained. In addition, a lease must be negotiated with the surface-rights owner.

Once the development for the field is selected, the locations of the drilling sites are known. A permit(a) for a 11 permanent roads to be constructed and for each well to be drilled must be obtained from the appropriate state and/or federal agency [USGS, BLM, BOIA (Bureau of Indian Affairs)]. This usually involves an actual inspection of the site. In addition, for a number of possible sites, a disclaimer stating that there are no important archeological sites present must be obtained.

\section{A.2.1 Site Preparation}

Once all the required permits and approvals have been obtained, work conmences on clearing and leveling of the site. The leveled area may be from $1 / 2$ to 5 acres, depending on the sizes of the drilling rig and stimulation job planned. A drill pit of approximately a few hundred square feet up to $1 / 2$ acre (included in the $1 / 2$ to 5 -acre total) is also constructed.

Some of these sites are on virtually level ground, while others may require extensive excavation, due to hilly locations. Some sites may be located on hills with more than a $30 \%$ slope, which may result in serious erosion problems. It is, however, important to remember that each and every site has been approved by the appropriate licensing agency and the surface rights owner.

(a) Permits: Virtually every state in the acquisition, exploration, and development of petroleum is licensed by some agency. On federal land, the BLM is in charge of leasing rights. Each drill site is inspected by the USGS. Each drilling program for each well is approved by the USGS. If the possibility of endangered species exists, the Wildlife Commission may be called in to help. State regulations are all handled through state oil and gas commissions or some equivalent agency. 


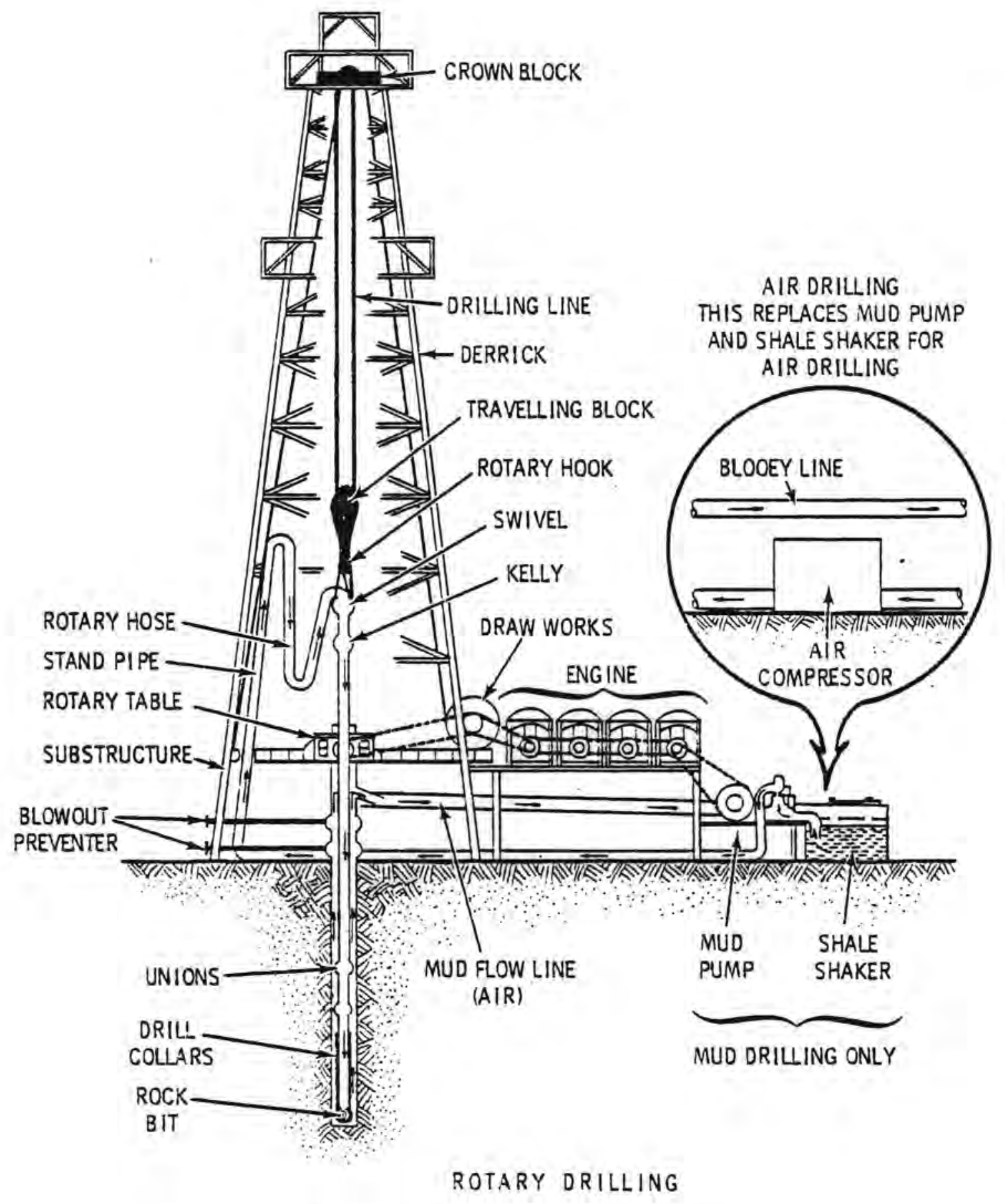

FIGURE A.1. Rotary Drilling Rigs 


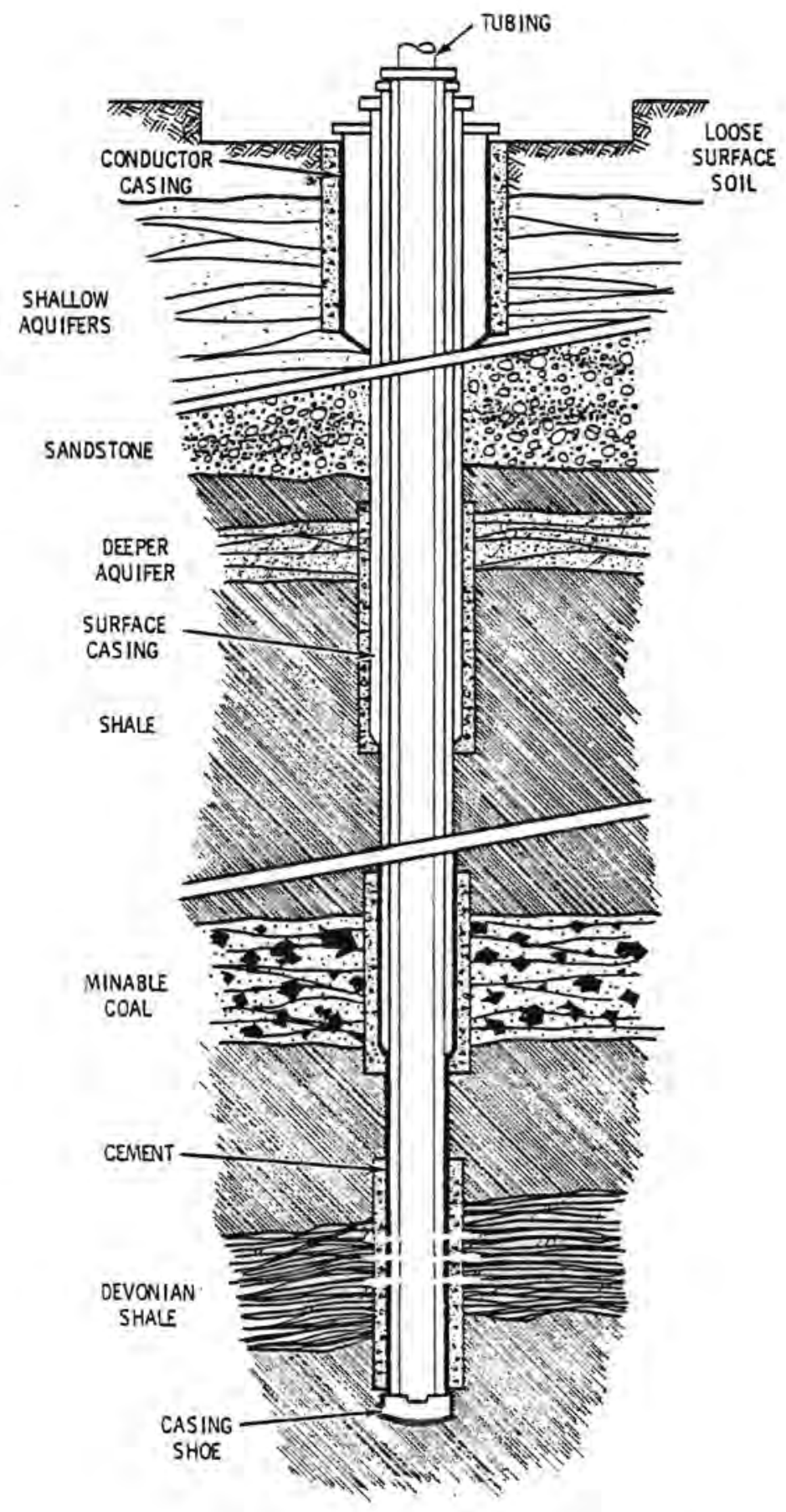

FIGURE A.2. Casing Strings and Pipe Used in an 011 Well

A-6 


\section{A.2.2 Drilling}

When a well is drilled, a certain zone is the target, whether it is a wildcat or developed well. The mud program is selected before drilling is started. Air or gas drilling is frequently used in place of mud drilling for low pressurized regions. An appropriate government (state) agency will have preset the depth for conductor and surface casing to be set. The well may be cored through all different zones of interest. Casing will usually be cemented across the producing interval. If problem zones are encountered, these will be isolated by the cementing of casing also.

\section{A.2.3 Completion}

Most gas wells are completed through casing which has been cemented in place. Once the cement is set, the well is completed by shooting shaped charges through the casing into the zones of interest. Upon completing the perforations, a small acid job may be run to clean up the well. Frequently, a larger hydraulic fracturing job will be run as well.

\section{A.2.4 Well Testing}

Once the well has been completed, it is normally tested. Each zone within the range is tested separately (isolating the zone by setting a packer between the zones). These tests will show the flow capacity and permeability of each zone of interest and may also be used to estimate the overall reserves present in each zone.

\section{A. 3 PRODUCTION}

The main surface facilities used during production include the well-head valves, a two- or three-phase separator (see Figure A.3) and surface storage facilities. On a regular schedule, a tanker will come to remove the condensate (assuming there is some). There may be a need to dispose of produced water, although this is very uncommon for wells completed in the Devonian shale. In addition, most companies have a routine well-logging program where temperature surveys, radioactive logs and other electronic logs are routinely run.

In the flow rate of the well drops off, a new hydraulic fracturing job may be instigated. Again, fracturing may occur on an almost routine time interval.

\section{A. 4 ABANDONMENT}

Once a well has reached the end of its productive life, it is abandoned. In a gas well, this occurs when the pressure has become too low to cause any gas to flow. Proper well abandonment procedures are very important and are regulated by either federal and/or state agencies. 

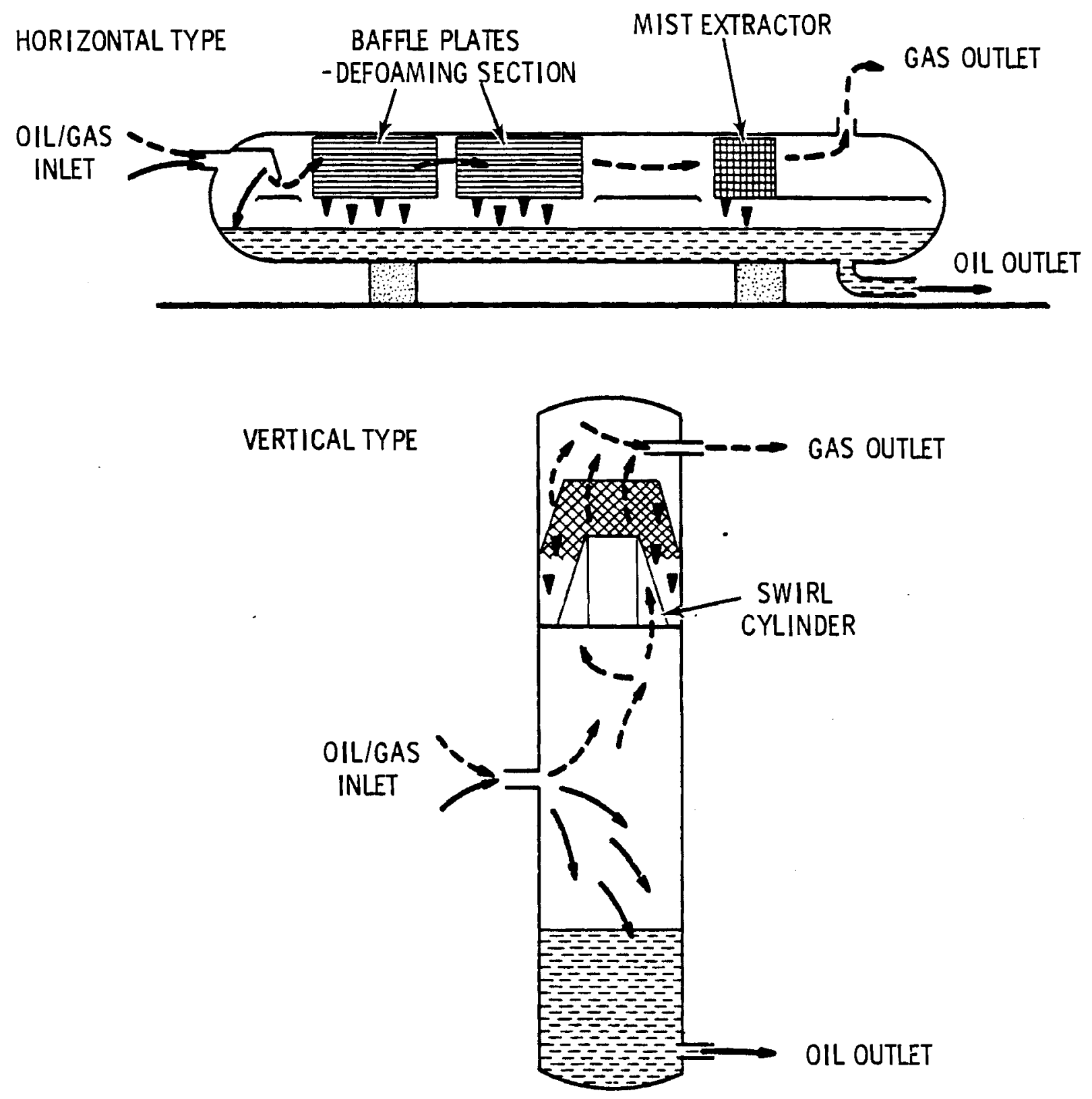

SEPARATORS

FIGURE A.3. Two-Phase Separator 
The steps used in abandonment are:

- Remove useable downhole tubing

- Plug and mark well

- Remove all surface facilities

- Site restoration.

If usable downhole tubing is present, it will be cut and removed from the well. The well will then be cemented to the surface and marked. The type and grade of cement as well as the marker are normally regulated by the oil and gas commissions of each state. All of the surface facilities such as tanks, separators, tubing and well-head valves are removed. Once the above steps have been completed, site restoration occurs.

Since most Devonian shale wells are located on private land, the nature of the site restoration is normally a negotiated part of the land-use lease. Typical steps may be the recontouring and reseeding of the well site and any road constructed. 


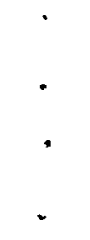


APPENDIX B

BARRIERS TO COMMERCIAL PRODUCTION 
Several technically feasible methods exist for recovering natural gas from Devonian gas shales. However, before this resource can become commercially viable, several barriers or issues must be resolved. These barriers are principally of a technical and economic nature. These barriers (with no order of importance implied) include:

- lack of risk capital

- legal constraints

- technological problems

- pipeline availability

- lack of drill rigs.

Each of these barriers is discussed in this section.

\section{B. 1 RISK CAPITAL AVAILABILITY}

Currently there is a lack of risk capital available for the exploitation of the Devonian gas shale. This lack of capital is caused primarily by:

- low productivity of existing wells

- poor success of wildcat wells

- competition from conventional reservoirs

- higher than normal drilling costs.

Risk capital for exploration is allocated on the basis of the potential profitability of all available areas for exploration. The profitability, in turn, is based on the potential size of the given reservoir and the potential rate of return, i.e., how fast the given well or field will produce gas for any given venture. Currently, the most attractive areas for exploration are the Tuscaloosa Trend (Louisiana), offshore, and the overthrust belt (Wyoming, Idaho, Utah, and Montana). The capital for exploration in the eastern or Devonian gas shale must be obtained after the funding of more promising areas. However, as demand and the price for domestic natural gas increases, Devonian gas shale will become a more attractive resource for exploration and production. Activities in the eastern gas shales may increase at that time. 
Low productivity of existing wells is a problem in terms of cash flow. It takes a great deal more time to recover the initial investment for wells which flow at low rates. The average rate of production in the Devonian shale is only on the order of 20 to $50 \mathrm{Mscfd}$, which may be compared to 1 MMscfd for production from a good conventional gas well. The Devonian shale gas is also produced at low initial pressure and will need compressors if it is put into a commercial pipeline. Compressors are not needed, however, if the gas is used locally. For local use, the low pressures and flow rates of Devonian shalegas should not be a barrier.

Allocation of funds for exploration is based on a number of factors. The final step in the exploration phase, the drilling of a well, is a very expensive and critical decision. $0 i l$ and gas companies will usually elect to drill into potential reservoirs which are composed of familiar materials such as sandstone, limestone, or dolomite. Even for companies which operate within regions where Devonian shale is found, numerous other more conventional targets for drilling are available. Drilling will most likely occur into these more conventional reservoir rocks. However, as more information becomes available about the Devonian shale resource and the technology for exploitation improves, funding may no longer be a major barrier.

Higher than normal drilling costs are a problem for the Devonian shale resource located in the Appalachian basin. In this area, the Devonian shale is located under a large number of mineable coal seams. To exploit the Devonian shale, an additional drill permit must be obtained from the owner of the coal. Even though the coal owner is paid, he may be reluctant to allow drilling because there will be a substantial pillar of coal that must be left unmined where the Devonian shale well is drilled. This should not be a barrier to exploitation of Devonian shale located within the Michigan and Illinois basins however, since the location of the Devonian shale resource in these basins is not thought to be underlying coal resources.

\section{B.2 LEGAL CONSTRAINTS}

The potential legal constraints associated with the production of gas from Devonian shale involves land usage and mineral rights ownership. Before any 
drilling activities can begin, property ownership must be established and a leasing agreement must be implemented. Leasing agreements must be obtained with both the surface landowner and the owner of the mineral rights.

The question of surface-rights ownership can sometimes be a problem. often property titles are not easily available, may not be up-to-date, or may be difficult to trace.

The potential problem of mineral. rights ownership may be more important than that of surface rights ownership. Historically, the lack of local records has been a problem in rural Appalachia. This makes mineral rights ownership difficult to determine because the primary alternative source of information is knowledge of individual property owners. Many of the local residents within this basin area have no knowledge of mineral rights ownership. If a title to the mineral-rights cannot be obtained, drilling cannot occur.

Current experience seems to indicate that while some time delays do occur, both property titles and mineral-rights ownership can be obtained. Therefore, legal constraints are not expected to be a significant barrier to the utilization of this resource.

\section{B.3 TECHNOLOGICAL PROBLEMS ASSOCIATED WITH EXPLOITATION OF DEVONIAN SHALE}

There are two,principal technological barriers associated with the exploitation of this resource. These barriers are:

- few successful wildcat wells

- lack of good resource description.

The major focus of DOE research has been delineation of the Devonian shale resource. Currently, new wells are found by stepping out from existing proven areas. This is a typical method of exploration for Devonian shale. In standard oil field practices, extensive geophysical and geological work determine where potential reservoirs may be located and then wildcats are drilled into these formations. To date there is no way of predicting where a good Devonian shale zone will be found. There is also a problem with 
determining which stimulation method is best because it seems to vary from area-to-area. For example, a stimulation method that works in Kentucky may not work for a similar well located in Ohio. This type of problem has been overcome for conventional resources. It appears that R\&D activities currently being implemented should overcome the current technical problems for this Devonian shale resource in a reasonable time frame.

\section{B.4 PIPELINE AVAILABILITY}

Insufficient pipeline capacity has been previously mentioned (Dept. of Energy 1979) as a potential barrier to increased utilization of our unconventional gas resources. There are two reasons why this should not be a barrier for the utilization of natural gas from Devonian shale:

- Nearness to large pipelines

- Potential for local usage with no pipeline.

Figure B.1 shows gas pipeline capacities in the United States. A large portion of the existing pipeline capacity is near the Devonian shale resource areas. Thus, there should be adequate pipeline capacity for the development of this resource.

In local usage, major transmission lines are not required. For example, the Benedictine Sisters of Erie (a convent) recently drilled and completed a gas well (Tri-City Herald, March 26, 1980). They anticipate this well will supply all of their natural gas needs. Another example of local usage is that of Houghton College of Houghton, New York (Dept. of Energy 1980). They have drilled and completed a Devonian shale well and hope that this well will supply most of their gas needs for winter heating. Similar usage by farms or smal1 industrial parks would be an ideal way to use this high-Btu, low-pressure gas. It appears that pipeline availability should be no problem in the development of this resource.

\section{B.5 LACK OF DRILL RIGS}

The lack of drill rigs is expected to subside in the future. The number of drill rigs and crews is currently expanding and with these expansion levels, there should be sufficient drill rigs available to reach the initial estimated goal of 1 TCF/year by the year 2000. However, a 1975 OTA report indicates that 


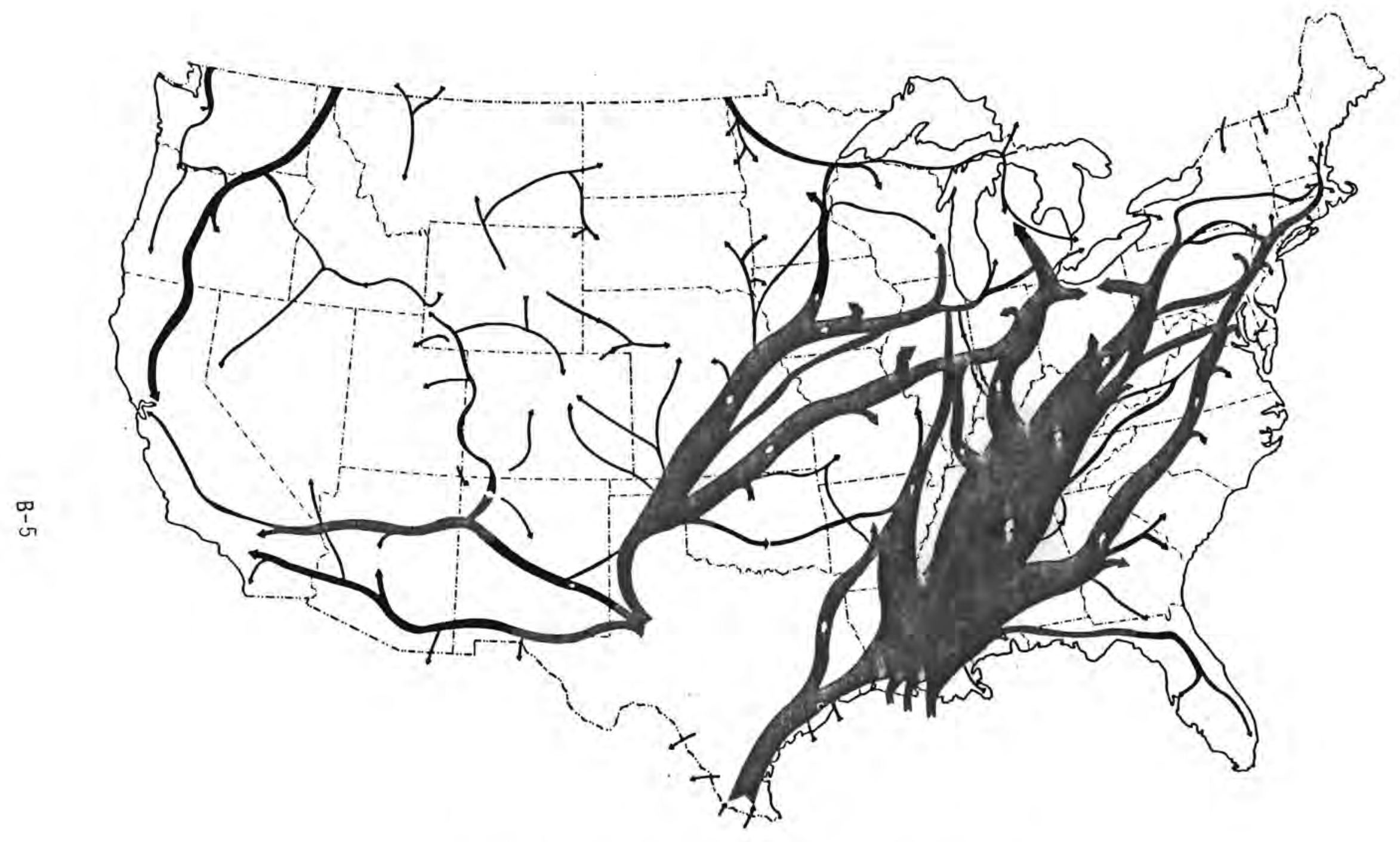

FIGURE B.1 Gas Pipeline Capacities in the U.S. 
only 73 drill rigs and from 65 to 75 completion and workover rigs are available in the Appalachian basin. Although most drill rigs came from new construction, regional allocation and competition for these rigs could be a problem. If there is no increase in the number of rigs, it will be difficult to drill enough wells to meet the goal of 1 TCF by the year 2000. A more recent study by the National Petroleum Council predicts that from 1 to 2 trillion cubic feet a year of gas will become available from this resource assuming only modest growth rates (12 to 15 new rigs and crewsper year) in the total number of drill rigs available. Thus, if reasonable growth rates do occur, this goal may not only be met but could be exceeded. 
APPENDIX C

GLOSSARY OF TERMS 


\section{APPENDIX $c^{(a)}$ \\ GLOSSARY OF TERMS}

Acidizing

Air Drilling

Anticline

Barrel

Bits

Blowout

B1owout Preventer

Borehole

Cable Tools

Casing

Casinghead Gasoline

Cellar

Cement
The pumping of hydrochloric or mud acid into a well to dissolve deposits of material and to open passageways for the oil to flow through.

Rotary drilling system using compressed air instead of mud as the circulation medium.

A subsurface geological structure in the form of a sine curve or an elongated dome. This type of formation holds petroleum.

A unit of measure for crude $0 i 1$ and oil products equal to 42 U.S. gallons.

The cutting tools used on the working end of the drilling string.

When excessive well pressure runs wild and blows the string and tools out of the hole.

Device consisting of a series of hydraulically controlled rams that can be triggered instantly to seal off a we11; a Christmas tree.

The hole in the earth made by the drill; the uncased drill hole from the surface to the bottom of the well.

The equipment necessary for cable-tool drilling of a we11. A heavy metal bar, sharpened to a chisel point, is attached to a rope or cable and is moved up and down.

Steel pipe used in the well to seal the borehole to pre= vent fluid escape and to keep the walls from collapsing.

"Natural gasoline" - actually the condensate from natural gas.

Area dug out beneath the drilling platform to allow room for installation of the blowout preventer.

Mixture used to set the casing firmly in the borehole. A slurry that is allowed to set until it hardens.

(a) Langenkamp; Berger and Anderson. 
Cementation

Cementing

Centralizers

Christmas Tree

Circulating System

Completion

Compressor

Compressor Station

Conductor

Confirmation We11

Connate Water

Core

Core Drilling

Core Sampling

Coring Bit

Crude $0 i 1$
The natural filling in of the pore spaces in a reservoir by 1 imestone.

Pumping the cement slurry down the well and back up between the casing and the borehole. Once hardened, the cement is then drilled out of the casing.

Devices fitted around the outside of the casing as it is put in place to keep it centered in the hole.

Array of valves, pipes, and fittings placed atop a free-flowing wel1.

The portion of the rotary drilling system that circulates the drilling fluids or mud.

Finishing a well. Getting a newly-drilled well ready for production.

Mechanical device used in the handling of gases much as a pump is used to increase the pressure of fluids. Also used to increase air pressure.

Placed at selected intervals along a gas pipeline, these units maintain the pressure necessary to keep the gas flowing through the lines.

Outer pipe near the top of the well used to seal off unstable formations or to protect ground water near the surface.

A well drilled to prove the formation or producing zone encountered by an exploratory or wildcat well.

The water, usually saline, present in a petroleum reservoir in the same zone occupied by $0 i 1$ and gas.

Literally a "plug" lifted or cut out of the earth at a predetermined depth.

Using a special bit for the purpose of cutting a core.

Taking out a core for geological examination of the composition of the strata at a particular depth.

A hollow bit designed to make a circular cut for a core sample.

$0 i 1$, unprocessed, just as it comes from the formation; unrefined petroleum. 
Darcies (d.)

Millidarcies (m.d.)

Microdarcies

Darcy's Law

Deviated Hole

Devonian

Diagenesis

Dinoseis $^{(8)}$

Directional Drilling

Dolomite

Drilling Mud

Dry Hole

Fault
Unit of measurement of permeability. Named after its originator Henry D'Arcy.

Since average permeability is usually less than one darcy, the measurement is expressed in mi11idarcies (m.d.) or one thousandth of a darcy.

Since average permeability is usually less than one darcy, the measurement of tight sands or shales is sometimes expressed as microdarcies or onemillionth of a darcy.

A porous medium has a permeability of one darcy when a single phase fluid of one centipoise viscosity (such as water) which saturates the pore space will flow at a rate of one centimeter per second per square centimeter of area under a pressure of one atmosphere.

Directional change from the absolute vertical in drilling either by design or accident.

Geologic period from about $405,000,000$ B.C. to $345,000,000$ B.C.

Process involving physical and chemical changes in sediment after deposition that converts it to consolidated rock.

The Dinoseis system also employs a heavy weight held in contact with the ground. However, the Dinoseis energy comes from the explosion of gases in a chamber attached to the weight.

The technique of drilling at an angle from the vertical by deflecting the drill bit.

A sedimentary rock. Possibly formed from limestone through the replacement of some of the calcium by magnesium.

A fluid consisting of water or oil, clays, chemicals and weighting materials used to lubricate the bit and flush cuttings out of the hole.

A well that fails to hit oil or gas, a "Duster."

A fracture in the earth's crust accompanied by a shifting of one side of the fracture with respect to the other side. 
Flares

Flow

Formation

Fracturing

Acidizing

Explosive Fracturing

Hydraulic Fracturing

Gas

Associated Gas

Unassociated Gas

Gas Drilling

Geophones

Geosyncline

Infil1 Wells

Interstitial

Isopach
To burn off excess or unwanted natural gas at a well or production site.

Movement of petroleum through the reservoir.

A sedimentary bed or series of beds sufficiently alike or distinctive to form an identifiable geological unit.

Artificially opening up a formation to increase permeability and the flow of oil to the bottom of a well.

The pumping in of an acid solution to dissolve limestone or other deposits.

Use of explosive charges to shatter a formation. May be fired through the sidewalls of the well.

Forcing formation open by pumping in liquid under pressure.

Any fluid, combustible or non-combustible, which is produced in a natural state from the earth and which maintains a gaseous or rarified state at ordinary temperature and pressure conditions.

Gas that occurs with oil, either as free gas or in solution.

Natural gas occurring alone, not in solution or as a free gas with oil or condensate.

Drilling process using gas as the circulating system, similar to air drilling but using natural gas.

Microphones plugged into the earth's surface used to detect seismic waves.

A linear depression in the earth's crust that subsided deeply during a long period of time.

Wells drilled to fill in between established producing wells on a lease; wells drilled to reduce the spacing between wells in order to increase production from the lease.

Water found in the pore openings of reservoir rock.

Isopach maps are drawn to illustrate the variations in thickness between the correlation markers. This is usually done by shading or coloring. 
Kel1y

Kick

Ki11 a Wel1

Killer Well

Landman

Lease

Lithology

Linewalker

Logging

Magnetometer

Mscfd

MMscfd

Mud Logger
The first and sturdiest joint of a drill column. A hollow, thick-walled, 40-foot joint of pipe that has four or more sides with threaded connections on each end to permit it to be attached to the swivel and to the drill pipe. Used to transmit torque from turntable to drill string and to move in a vertical direction during drilling.

Pressure from down-hole in excess of that exerted by weight of the drilling mud, causing loss of circulation. If the gas pressure is not controlled by increasing the mud weight, a kick can violently expel the column of drilling mud resulting in a blowout.

To overcome downhole pressure in drilling a well by the use of drilling mud or water.

A directional well drilled near an out-of-control well to kill it by flooding the formation with mud.

A person whose primary duties are managing an oil company's relations with its landowners. Such duties include securing of oil and gas leases, lease amendments, and other agreements.

A legal document giving one party rights to drill for and produce petroleum on real estate owned by another.

Study, description, and classification of rocks.

A pipeline inspector who walks the length of the line looking for leaks or potentially hazardous situations.

The lowering of various types of measuring instruments into a well and gathering and recording data on porosity, permeability, types of fluids, fluid content and lithography.

Device which detects minute fluctuations in the earth's magnetic field and shows the presence of sedimentary rock.

1 thousand standard cubic feet per day.

1 million standard cubic feet per day.

Person who analyzes the cuttings brought up with the drilling mud from the hole. 
Mud Program

"Natural Gas"

Offset We11

$0 i 1$

Pay Sands

Perforating

Permeability

Pig

Plugged Back

Pores

Porosity

Proppant

Proven Reserves

Ram
Planning for the supply of and use of drilling fluids in the drilling process.

Gases and all other liquid hydrocarbons not defined as oil.

A well drilled on the next location to the original well. The distance between the two wells depends upon spacing regulations.

All liquid hydrocarbons which are produced at the well in liquid form by ordinary oilfield production methods, and which are not the result of condensation of gas before or after it leaves the reservoir.

The zone of production - where oil and/or gas is found in commercially feasible amounts.

Literally punching holes in the casing so the oil and gas can flow into the well from the formation.

A measure of the resistance offered by a porous rock to the movement of fluids through it.

Device sent through a pipeline to clean it out.

To plug off a well drilled to a lower level in order to produce from a formation nearer the surface.

The void spaces between the rocks in a reservoir.

The capacity of rock to hold liquids in the pores.

Material used in hydraulic fracturing for holding open the cracks made in the formation.

$0 i 1$ and gas deposits that have been discovered and determined to be recoverable but are still in the ground.

A valve that causes closure on a blowout preventer stack; a hydraulically operated valve designed to shut in a well. A ram may be used to close the tubing or drill pipe. As a last resort, to prevent a blowout, a shear ram can be used which cuts the drill pipe. 
Reservoir

Reservoir Fluid

Rocks-Igneous Rock

Rocks-Magma

Rocks-Metamorphic Rock

Rocks-Sedimentary Rock

Roughneck

Sa1t Domes

Sands tone

Sediment

Sedimentary Rock

Separator

Seismograph

Shale

Shut-Down - Shut-In Well
A porous, permeable, sedimentary rock formation or trap holding an accumulation of petroleum enclosed or surrounded by layers of less permeable rock; a structural trap; a stratigraphic trap.

Crude 011 , natural gas, and salt water.

The "first" rock, formed as the molten magma cooled.

Rock in its molten state.

Created from sedimentary rock subjected to great heat and pressure.

Created under extreme pressure from particles of sediment.

Drilling crew members who assist the driller.

Salt plug forced upward by the accumulation of petroleum beneath it.

Sedimentary rock composed of grains of sand cemented together by other materials.

Particulate matter carried along with water which settles to the bottom of the body of water.

Rocks composed of sediments forced together under great pressure. See rocks.

Device placed between well head and lease tank battery to separate crude $0 i 1$ from natural gas and water.

Extremely sensitive recording device capable of detecting earth tremors as used in oil exploration to record man-made shock waves.

Rock composed of clay and fine-grain sediments.

There is a great difference between a shutdown well and a shut-in well. A well is shut down when drilling ceases which can happen for many reasons: equipment failure, waiting for equipment, waiting for cement, etc. A well is shut in when its wellhead valves are closed, shutting off production. A shut-in well is often waiting for pipeline construction. 
Spud

Squeeze or Squeeze Cementing

Step-Out Well

Syncline

TD

Tectonic Map

Tight Hole

Traps

Trip

TVD

Unconformity

Vibroseis ${ }^{\otimes}$

Viscosity

Well Shooter
To begin the drilling of a new well.

To seal off with cement a section of a well where there is a leak either allowing water in or oil out.

A well drilled adjacent to a proven well but located in an unproven area.

Rock formation folded downwards.

Total depth.

A geological map; a structural map showing the folding and faulting of subsurface formations.

A well being drilled about which all information depth, formations encountered, drilling rate, logs is kept secret by the operator.

A geologic structure which halts the movement of a petroleum accumulation.

Pulling the drill pipe from the hole to change the bit and running the drill pipe and new bit back in the hole.

Total vertical depth. TVD is always less than a well's TD because of the inevitable deviations from the vertical of the well bore.

A cap of rock laid down across the cut off surfaces of lower beds.

Mechanical means of producing shock waves for seismographic exploration without the use of explosives.

The ability of a fluid to flow. The more viscous a fluid is the less readily it will flow.

A person who uses nitroglycerin and other explosives to increase the diameter of the well bore. The explosives are lowered into the well bore by a wire line and are detonated electrically at the proper depth. 
Wildcat We11

Wildcatter

Wireline

Workover

Zone

Zones of Lost Circulation
A well drilled in an unproved area far. from a producing well; an exploratory well.

An operator who drills the first well in an unknown or unproven territory.

A "rope" or cable made of steel wire.

Cleaning, repairing, servicing, reopening, or perhaps drilling deeper, or plugging back, a well to secure continued or additional production.

An interval of subsurface formation containing one or more reservoirs.

Crevices, caverns, or very porous formations in which the drilling mud is lost and does not return. 


\section{REFERENCES}

Adamson, M. A. 1978. Environmental Report: Enhanced-Gas Recovery Project, Gallier County, Ohio. UCID-17945, Lawrence Livermore Laboratory, Livermore, CA.

American Petroleum Institute. 1976. Review of Fatal Injuries in the Petroleum Industry for 1975. Washington, D.C.

American Petroleum Institute. 1980. Summary of Occupational Injuries and I11nesses in the Petroleum Industry. Washington, D.C.

Bastress, E. K. 1978. "Utilization Options for Coalbed Methane." In: Proceedings from Conference on Methane Gas from Coalbeds, Development, Production and Utilization.

Berenson, A. S. 1975. Control of Communicable Disease in Man. 12th Edition, American Public Health Association, Washington, D. C.

Berger, B. D., and K. E. Anderson, Modern Petroleum, A Basic Primer of the Industry.

Clusen, R. 1979. Regional Issue Identification and Assessment First Annual Report. Department of Energy, Washington, D.C.

Copenhaven, E. D., R. J. 01 son and P. L. Rioe. 1978. Regional Energy-Environmental Data Book: Southern Region. ORNL-5443. Oak Ridge National Laboratory, Oak Ridge, TN.

Cotteneau, P. H. 1978. Effect of Sonic Boom from Aircraft on Wildlife and Animal Husbandry in Effects of Noise on Wildlife. J. L. Fletcher and R. G. Bushel, ed., Academic Press Inc., New York, NY.

Council of Environmental Quality. 1979. Off-Road Vehicles on Public Lands. CEQ-722, Jackson Place N.W., Washington, D.C.

Cremean, S. P., et a1. 1979. Massive Hydraulic Fracturing Experiments of the Devonian Shale in Lincoln County, West Virginia. METC/CR-79/17, Morgantown Energy Technology Center, Morgantown, WV.

Department of Energy. 1980. Unconventional Gas Resources. Morgantown Energy Technology Center, Morgantown, WV.

Department of Energy. 1979. Unconventional Gas Recovery (Enhanced Gas Recovery). DOE/EDP-0049. Washington, D. C.

Department of Energy. 1979. Semi-Annual Report for the Unconventional Gas Recovery Program. METC/SP-79/8. Morgantown Energy Technology Center, Morgantown, WV. 
Department of Energy. 1979. Environmental Readiness of Emerging Energy

Technologies. Summary Report, DOE/ERD-0022. Washington, D.C.

Department of Energy. 1978. Semi-Annual Report for the Unconventional Gas

Recovery Plan, METC/SP-79-4. Vol. 1. Morgantown Energy Technology

Center, Morgantown, WV.

Department of Energy. 1978. Environmental Readiness Document: Enhanced Gas Recovery. Commercialization Phase III Planning. D0E/ERD-0011. Washington, D.C.

Energy Research and Development Administration. 1976. Devonian Shale: Production and Potential. MERC/SP-76/2. Morgantown Energy Research Center, Morgantown, WV.

Environmental Reporter. 1979. 10(7):230, Bureau of National Affairs, Washington, D.C.

Ethridge, L. J. et a1. 1980. An Assessment of Environmental Health and Safety Issues Associated with the Commercialization of Unconventional Gas Recovery: Methane from Coal Seams. PNL-3413. Pacific Northwest Laboratory, Richland, WA.

Fields, H. H., S. Krickovic, A. Sainato, and M. G. Zabetakis. 1973. Degasification of Virgin Pittsburgh Coalbed through a Large Borehole. RI 7800 , U.S. Bureau of Mines, Washington, D. C.

Frohne, K. H. 1977. Large Scale Foam Fracturing in the Devonian Shale - A Field Demonstration in West Virginia. MERC/TPR-77/2. Morgantown Energy Research Center, Morgantown, WV.

Ham, J., and L. Dewey. 1978. Commercialization Plan for Unconventional Natura 1 Gas Resources. Department of Energy, Washington, D. C.

Howard, G. C. and C. R. Fast. 1970. Hydraulic Fracturing. Henry L. Doherty Memorial Fund of AIME, Society of Petroleum Engineers of AIME, New York, NY.

Howard, J. F., S. J. Lahoda, W. E. Zirk, and C. A. Komar. 1979. Gas Production of Devonian Shale Wells Relative to Photo Linement Locations: A Statistical Analysis. METC/CR-79/28. Morganton Energy Technology Center, Morgantown, WV.

Janssen, R. 1978. Noise and Animals: Perspectives of Government and Public Policy in Effects of Noise on Wildlife. J. L. Fletcher and R. G. Bumel, ed., Academic Press Inc., New York, NY.

Journal of Petroleum Technology. 1981 "TIC Facts: America's Potential Gas Supply."

Langenkamp, R. D., Handbook of $0 i 1$ Industry Terms and Phrases, Second Edition.

Myers, P. S. et al. 1970. "Nation's Cost/Benefit Ratio Weighs Heavil on Auto Emission." SEA Journal.

National Interim Drinking Water Regulations. 1976. U.S. Environmental Protection Agency, office of water suppty, Washington, D.C. 
National Petroleum Council's Report on Unconventional Gas Resources. 1980.

Vol. III. Devonian Shales Gas Resources. Washington, D.C.

National Safety Counci1. 1977. Accident Facts. Chicago, IL.

Office of Technology Assessment. 1977. Status on the Gas Potential from Devonian Shales of the Appalachian Basin. Washington, D.C.

Pakisen, L. C. et al. 1969. "Earthquake Predictions and Control." Science $166: 1476-1474$.

Riedel, E. F., G. A. Rotariu, and A. J. Goldberg. 1980. "Potential Barriers to Increased Production of Natural Gas from Unconventional Sources." PNL-SA-8641, Presented at the American Institute of Chemical Engineers, Fuels and Petrochemical Division, 88th National Meeting, Philadelphia, PA.

Riede1, E. F., et a1. 1980. An Assessment of Environmental Health and Safety Issues Associated with the Commercialization of Unconventional Gas Recovery: Tight Western Sands. PNL-3391. Pacific Northwest Laboratory, Richland, WA.

Sax, N. I. 1957. Dangerous Properties of Industrial Materials. Reinhold Publishing Corp., New York, NY.

Science Applications, Inc. 1977. Eastern Gas Shales Project: A Special Publication on Unconventional Gas from Shales. MERC/SP-77/33. Morgantown, WV.

Tonnessen, K. A. 1977. Environmental Impact Assessment: Chemical Explosive Fracturing Project, Petroleum Technology Corporation. Leslie, Letchen and Perry Counties, KY. UCID-17475, Lawrence Livermore Laboratory, Livermore, CA.

Tri-City Herald, March 26, 1980. "Nun's Gamble Pays Off." Kennewick, WA.

Turk, A., J. Turk and J. T. Wittes. 1972. Ecology, Pollution, Environment. W. B. Saunders Company, Philadelphia, PA.

USEPA. 1972. Compilation of Air Pollutant Emission Factors. Office of Air Programs. Report No. AP-42. Research Triangle Park, NC.

Usibelli, A., Peter Diebler, and Jayant Sathaye. 1980. The Geopressured Geothermal Resource of the Texas and Louisiana Gulf Coast: A Technology Characterization and Environmental Assessment. LBL-11539. Lawrence Berkeley Laboratory. University of California, Berkeley, CA.

Wescott, T. F. and A. F. Smith. 1979. "Digital Image Processing and Enhancement of Landsat Data for Lineament Mapping and Natural Gas Exploration in Appalachian Region." Presented at Third Eastern Gas Shales Symposium. METC/SP-79/6. Morgantown Energy Technology Center, Morgantown, WV. 


.




\section{DISTRIBUTION}

No. of

Copies

C. Atkinson

Department of Energy

Las Vegas, NV 89114

A. A. Churm

DOE Chicago Patent Group

9800 South Cass Avenue

Argonne, IL 60439

27 DOE Technical Information Center

S. Ba110u

Argonne Nationa1 Laboratory

9700 South Cass Avenue

Argonne, IL 60439

J. A. Coleman

DOE Office of Environmental Programs

Washington, D.C. 20545

R. M. Davis

Oak Ridge Nationa 1

Laboratory

P. 0. Box $X$

Oak Ridge, TN 37830

C. W. Edington

DOE Office of Health and Environmental Research

Washington, D.C. 20545

W. Esseiman

Electric Power Research Institute

P. 0. Box 10412

Pa1o A1to, CA 94304

W. 0 . Forster

DOE Office of Health and Environmental Research Washington, D.C. 20545
No. of

Copies

K. Frohne

Morgantown Energy Technology Center

Collins Ferry Road

Morgantown, WV 26505

W. Fulkerson

Oak Ridge National Laboratory

P. 0. Box $X$

Oak Ridge, TN 37830

M. J. Garre11

Ade1 phi University

New York, NY 10001

W. Gwillian

Morgantown Energy Technology Center

Col1ins Ferry Road

Morgantown, WV 26505

T. Harris

DOE Office of Environmental Programs

Washington, D.C. 20545

L. Henning

Electric Power Research Institute

P. 0. Box 10412

Palo A1to, CA 94304

L. J. Hoover

Argonne National Laboratory

9700 South Cass Avenue

Argonne, IL 60439

P. W. House

DOE Office of Environmental

Programs

Washington, D.C. 20545 
No. of

Copies

J. Jaksch

Los Alamos Scientific Laboratory University of California

P. 0. Box 1663

Los Alamos, NM 87545

C. Komar

Morgantown Energy Technology Center

Collins Ferry Road

Morgantown, WV 26505

D. Layton

University of California

Lawrence Livermore Laboratory

P. 0. Box 808

Livermore, CA 94550

R. K. Lohrding

Los Alamos Scientific Laboratory

P. 0. Box 1663

University of Cal ifornia

Los Alamos, NHA 87545

H. McCammon

DOE Office of Health and

Environmental Research

Washington, D.C. 20545

W. J. McCool

DOE Office of Environmental

Compliance and Overview

Washington, D.C. 20545

P. M. Meier

Building 475

Brookhaven National Laboratory

Upton, NY 11973

D. M. Monti

DOE Office of Environmental

Programs

Washington, D.C. 20545
No. of

Copies

W. D. Moore III, Drilling Editor

$0 i 1$ \& Gas Journal

1200 S. Post Oak Road

P. 0. Box 1941

Houston, TX 77001

P. Moskowitz

Brookhaven National Laboratory

Upton, NY 11973

W. E. Mott

DOE Office of Environmental Compliance and Overview

Washington, D.C. 20545

G. J. Rotariu

DOE Office of Environmental Programs

Washington, D.C. 20545

A. Rudolph

Battelle Memorial Institute 505 King Avenue

Columbus, $\mathrm{OH} 43201$

R. D. Shul1

DOE Office of Environmental Programs

Washington, D.C. 20545

W. E. Siri

University of California

Lawrence Berkeley Laboratory

Berkeley, CA 94720

D. H. Slade

DOE Office of Health and Environmental Research

Washington, D.C. 20545

E. Swenson

Resource Applications

Department of Energy

Washington, D.C. 20545 
No. of

\section{Copies}

J. Swinebroad

DOE Office of Health and Environmental Research Washington, D.C. 20545

R. Uhler

Electric Power Research Institute

P. 0. Box 10412

Palo Alto, CA 94304

Henry F. Walter

DOE/ESED

EP-142

Washington, D.C. 20545

B. W. Wachholz

DOE Office of Environmental

Programs

Washington, D.C. 20545

E. R. Williams

DOE Office of Environmental

Programs

Washington, D.C. 20545

B. Wise

Morgantown Energy Technology Center

Collins Ferry Road

Morgantown, WV 26505

R. W. Wood

DOE Office of Health and Environmental Research Washington, D.C. 20545

T. York

Resource Applications

Department of Energy

Washington, D.C. 20545
No. of

Copies

ONSITE

DOE Richland Operations Office

H. E. Ranson

HARC

J. A. Herbert

17 Pacific Northwest Laboratory

W. J. Bair

D. L. Brenchley

S. Marks

R. E. Rhoads (6)

L. D. Williams

Publishing Coordination (2)

Technical Information Files (5) 
: 